〔Med. Entomol. Zool. Vol. 61 No. 3 p. 281-308 2010]

\title{
Redescriptions of five species of the genus Armigeres, subgenus Armigeres (Diptera: Culicidae) collected from fallen coconut fruits at the coastal plains of Sarawak, East Malaysia
}

\author{
Takako TomA ${ }^{1)}$, Ichiro Miyagi ${ }^{1), 2)}$, Takao OkAzAwA ${ }^{3)}$, \\ Yukiko $\mathrm{HigA}^{4)}$ and Moi Ung $\mathrm{LEH}^{5)}$ \\ 1) Laboratory of Medical Zoology, School of Health Sciences, Faculty of Medicine, \\ University of the Ryukyus, Nishihara, Okinawa, 903-0215 Japan \\ 2) Laboratory of Mosquito Systematics of Southeast Asia and Pacific, c/o Ocean Health \\ Corporation, 4-21-11, Iso, Urasoe, Okinawa, 901-2132 Japan \\ 3) International Student Center, Kanazawa University, \\ Kakuma, Kanazawa, Ishikawa, 920-1192 Japan \\ 4) Department of Vector Ecology and Environment, Institute of Tropical Medicine (NEKKEN), \\ Nagasaki University. Sakamoto 1-12-4, Nagasaki, 852-8523 Japan \\ 5) Sarawak Museum, Department, 93566, Kuching, Sarawak, Malaysia
}

(Received: 30 March 2010; Accepted: 18 May 2010)

\begin{abstract}
Adults, male genitalia, pupae and larvae of five species of the genus Armigeres, subgenus Armigeres-Ar. confusus Edwards, Ar. jugraensis (Leicester), Ar. moultoni Edwards, Ar. malayi (Theobald) and Ar. setifer Delfinado-are redescribed and illustrated in detail based on specimens collected from fallen coconut fruits with holes made by small animals at the coastal plains of Kuching, Sarawak, East Malaysia. Keys to adults, male genitalia, pupae and larvae of the species are also provided.
\end{abstract}

Key words: mosquitoes, Culicidae, Armigeres (Armigeres), redescriptions, Sarawak, Malaysia

\section{INTRODUCTION}

The genus Armigeres Theobald, 1901 is primarily Oriental in distribution but widespread and well represented in the Indomalayan and Australasian regions as well as Japan (Knight and Stone, 1977). Two subgenera are recognized, Armigeres Theobald, 1901 and Leicesteria Theobald, 1904 (Edwards 1917; Barraud 1934). As far as we know, of the 58 species in the genus, 41 are in the subgenus Armigeres and 18 in the subgenus Leicesteria (WRBU, 2010).

The adult males of the species are mostly well defined and can be easily identified by coloration of the abdominal sterna and male genital structures, such as gonostylus, phallosome and setae on the basal dorsomesal lobe. However, the larvae and pupae of the species have not been described in detail, and are difficult to separate.

During a recent mosquito survey in Sarawak, East Malaysia from August to September in 2005 and 2006, we found many larvae and pupae of the subgenus Armigeres species at coastal coconut farms in Sampadi and Asajaya, Kuching District. The immatures of the species were found mainly in fallen green coconut fruit with a small hole bored by small animals such as rats and treeshrews (Tupai spp.) (Fig. 11B). The Armigeres 
larvae are usually abundant in such damaged fruits containing turbid water with a great deal of decaying coconut meat. Usually, immatures coexist with several closely related species of the subgenus in a single fruit.

Among the specimens collected from the coconuts, five species; Ar. confusus Edwards, 1915, Ar. jugraensis (Leicester), 1908, Ar. moultoni Edwards, 1914, Ar. malayi (Theobald), 1901 and Ar. setifer Delfinado, 1966 were identified by the male genitalia (Edwards, 1914, 1915, 1917; Leicester, 1908; Thurman,1959; Delfinado, 1966). The original descriptions of the former three species of adults are brief and the immatures were not described, so we describe and illustrate the adults and immature stages in detail in this paper. As existing detailed descriptions of Ar. malayi and Ar. setifer (Steffan, 1968; Thurman, 1959; Delfinado, 1966; Toma et al., 2007), outlines are given briefly. In addition, keys to the adults, male genitalia, larvae and pupae of these 5 species collected from the coconut farms are also presented.

\section{Materials And Methods}

To establish morphological relationships between the immatures and adult males and females, and the larvae collected from the coconuts and oviposition traps (plastic containers with polluted water) were individually reared in the laboratory of the Sarawak Museum in Kuching. A series of about 200 adult male and female specimens were obtained with the associated larval and pupal exuviae, and mounted on slides for further taxonomic studies. The illustrations of the abdominal ornamentation were based mainly on fresh specimens, as deformity in the colorations of the sterna occurs in dry specimens. Measurements were made on pupal exuviae and whole fourth-instar larvae. All descriptions and illustrations were prepared from 3 to 5 adults, 5 to 6 pupal exuviae and 5 to 8 whole larvae. In the pupae, the trumpet index is the ratio of the length to the width of pina and paddle index is the length to the mid width (see Fig. 2A). The siphonal index of the larvae is the ratio of the length to the width at $1 / 2$ siphon length. The chaetotaxy of pupae and larvae were examined and the modal condition for the branching of setae is shown in the illustrations. Range of variation in the branching of setae together with notes on aciculation is shown in pupal and larval chaetotaxy tables. Abbreviations used in the specimens examined are L for larva, $\mathrm{P}$ for pupa, $\mathrm{G}$ for male genitalia. An asterisk $\left.{ }^{*}\right)$ in the stages described indicates that at least some portion of that sex or stage is figured.

The type specimens of Ar. confusus, Ar. jugraensis and Ar. moultoni preserved in the Natural History Museum, London in 1996 and Ar. setifer in the Walter Reed Biosystematic Unit, Museum Support Center, Smithsonian Institution, Washington, DC in 1997 were examined. The terminology used for the adults and the male genitalia follows mainly Harbach and Knight (1980, 1981), and for the chaetotaxy of pupa and larva follows Belkin (1962). Most of the specimens used for descriptions of the species in this paper are deposited in the collection of the Sarawak Museum and in the laboratory of Medical Zoology, School of Health Sciences, Faculty of Medicine, University of the Ryukyus, Japan.

\section{Subgenus Armigeres Theobald}

The main features of the subgenus Armigeres (Fig. 10H) are as follows: Female palpus is short, at most $1 / 4$ the length of proboscis; the male palpus is longer than proboscis by $1 / 2-3 / 4$ the length of the terminal segment. Torus usually with lateral white scales. Proboscis long and slightly curved downward, laterally compressed in apical half, 
covered uniformly by dark scales. Scutum bordered laterally with pale scales that are very clear in the male. Alula and squama are fringed. Postspiracular setae are present; one or two lower mesepimeral setae are present; pleuron with patches of white scales. Usually foreungues are unequal, more or less larger than mid and hidungues. Midungues are equal in size, with or without a tooth. Hindungues are equal in size, without a tooth. The male genitalia are distinctive for each species and clearly different from the species of the subgenus Leicesteria. Generally, the larvae of the subgenus Armigeres have a short stout siphon with one weak siphonal seta, lacking pecten teeth and an anal segment with a small dorsal saddle. Usually the pupae are easily distinguished by the paddle with filamentous fringe on the apical margin and a short broad trumpet. No characters clearly separate the two subgenera of larvae and pupae (Thurman, 1959; Delfinado, 1966).

\section{Armigeres (Armigeres) confusus Edwards, 1915}

(Figs. 1-3, Tables 1, 2)

Armigeres confusus Edwards, 1915. Bull. Entomol. Res. 5: 283 (우, ○). Type locality: Kuching, Sarawak, Malaysia

Armigeres (Armigeres) confusus Edwards: Brug, 1931. Arch. Hydrobiol., Supple 1.-bd. 9, Tropische Binnengewasser 2: 32 (L*).

Specimens Examined. The following specimens were collected as larval and pupal stages from fallen damaged coconut fruits and artificial containers (oviposition traps) at a coconut farm in Sampadi, Kuching, Sarawak in August and September of 2005 and 2006 by T. Toma and I. Miyagi. 10 (050928-23) on pin with male genitalia (G52) and larval and pupal exuviae, L, P (108) on slides; 10 (050928-4) with (G75); 1우 (060828-14) with (G

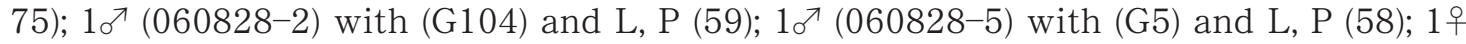
(060922-4) with L, P (339); 1우 (060922-6) with L, P (267); 107 (060922-18) with (G47) and

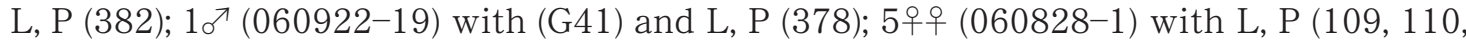

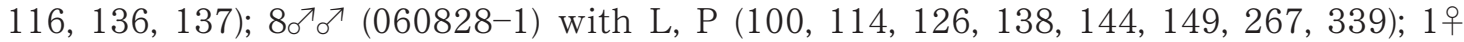
(060928-9) with L, P (126); 1 whole larva (050924-5); 1 whole larva (050928-14); 6 whole larvae (060928-18).

\section{Description.}

Female (Fig. 1G-I).

Wing, 4.25-4.50 mm. Proboscis, 2.25-2.65 mm. Forefemur, 2.50-2.70 mm. Abdomen, $4.05 \mathrm{~mm}$.

Head: Narrow band of white scales along ocular line, broadening ventrally in postgenal area. Vertex covered with flat, broad, dark scales, except for small central patch of pale scales. Erect scales all dark, forked and restricted to occiput region of the head. Clypeus bare. Antenna pedicel integument dark, with small white scales densely on inner and lower sides. Anntena pilose 2.5-2.9 $\mathrm{mm}$ long.

Thorax: Integument brown to dark brown. Scutum covered densely with narrow, curved, dark brown scales. A narrow curved white scale line extending from the anterior pronotum, gets broader over the paratergite and ends at the wing root. A few white scales present at center of the prescutellar area. Acrostichal, dorsocentral and scutal fossal setae absent. A few prescutellar and patches of several well developed supraalar setae present. Scutellum covered with flat, dark brown scales, with a few white scales at the posterior margin of each lobe, conspicuous in mid lobe. 5-8 conspicuous setae arising on each lobe. Mesopostnotum bare, integument brown. Antepronotal lobes covered by small white scales on front and sides; top and posterior margin with brown setae. Upper 

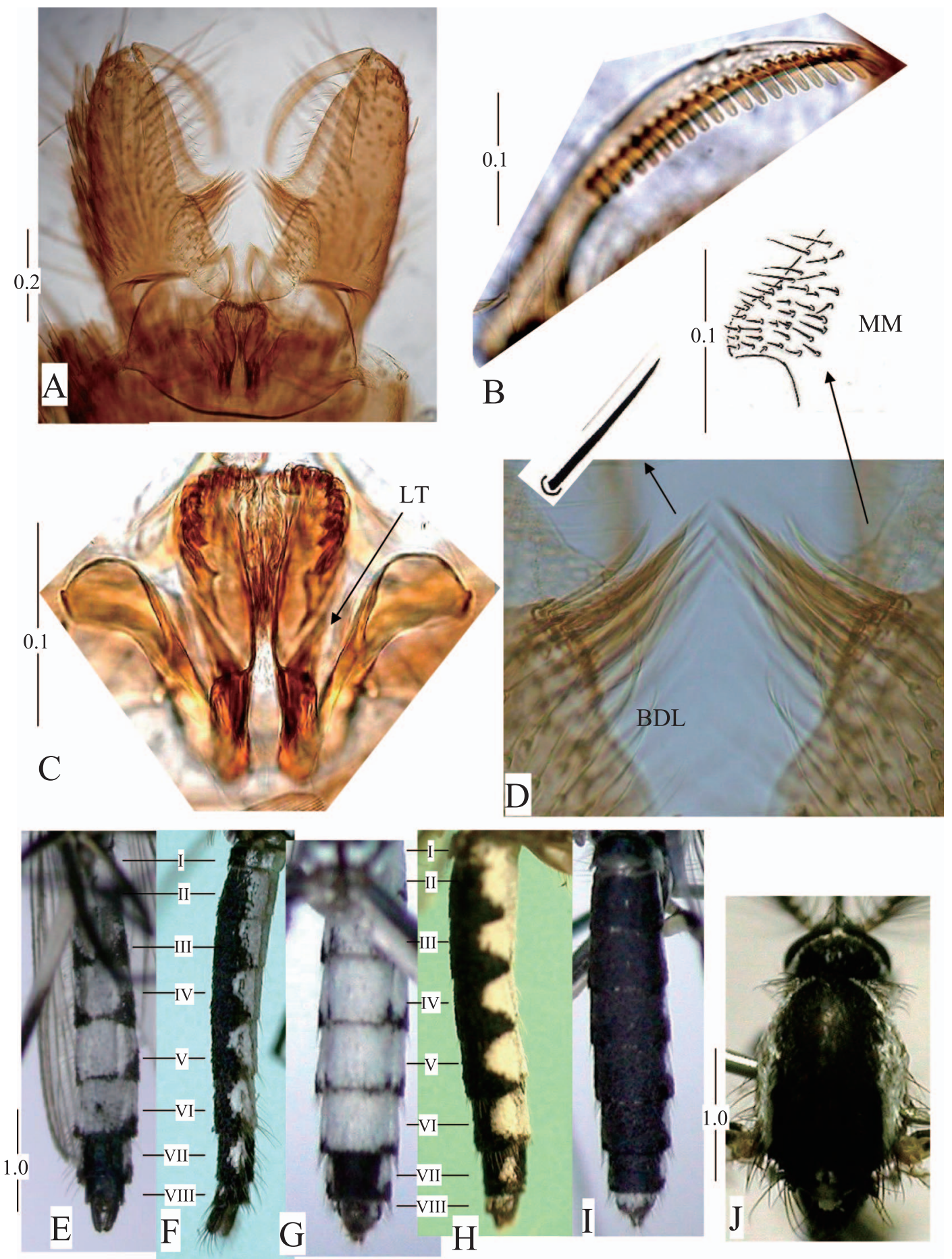

Fig. 1. Adult male (A-F, J) and female (G-I) of Armigeres (Armigeres) confusus. A, structures of genitalia (ventral aspect); B, gonostylus; C, phallosome (vental aspect); D, basal dorsomesal lobe (BDL) with lanceolate setae and mesal membrane (MM); E and $\mathrm{G}$, abdominal sterna (ventral aspect); $\mathrm{F}$ and $\mathrm{H}$, abdomen (lateral aspect); I, abdominal terga (dorsal aspect); J, scutum and scutellum (dorsal aspect); LT, large teeth of Phallosome. Scales: mm. 
half of postpronotum covered with narrow dark scales; central part and posterior border with white scales; a row of 4-6 setae along posterior border. Postspiracular area with a patch of white scales. Paratergites with a patch of white scales. Mesokatepisterum with two large, upper and lower patches of white scales; a row of several setae on the posterior border and about 10 pale setae on the prealar knob. Mesanepimeron with a large patch of white scales; single lower mesepimeral pale seta and a dense patch of upper mesepimeral pale setae present. Postprocoxal membrane with white scales. Mesomeron bare.

Legs: Fore coxa covered with white scales and dark setae; mid and hind coxae with a patch of white scales on the anterior side with yellowish setae; fore and mid femora with a line of white scales on the ventral side to knee; hind femur with a broad line of white scales on outer aspect to knee. Rest of legs covered with dark scales. Ungues of fore leg as small as mid and hindunges, subequal in size, both with a submedian tooth.

Wing: Cell $\mathrm{R}_{2}$ about 1.50-1.60 times the length of its stem. Anal vein ending well beyond fork of $\mathrm{Cu}$. Alula with a row of small scales; upper calypter with a row of long hair-like scales.

Halter: Capitellum dark, rest light in color.

Abdomen (Fig. 1G-I): Terga I-VII dark scaled on dorsal aspect, with patches of white scales laterally; tergum VIII basal $2 / 3$ with white scales, rest dark scaled. Sterna II-VI entirely white scaled without apical dark bands; VII dark scaled; VIII mostly dark scaled.

Male (Fig. 1A-F, J).

Wing, 4.0-4.32 mm. Proboscis, 2.25-2.95 mm. Palpus, 2.88-3.40 mm. Forefemur, 2.63-2.78 $\mathrm{mm}$. Resembles the female except in the following characters.

Head: Palpus 1.14-1.27 the length of the proboscis. Antenna 2.40-2.50 mm long.

Thorax: Border of white scales around scutum much broader than in female and extending further back over wing roots (Fig. 1J). A patch of white scales in prescutellar area also larger. Median scutellar with a large patch of white scales. Postpronotum with numerous narrow pale scales on upper half; pale scales in lower half are slightly broader. Paratergites are entirely covered with white scales.

Abdomen: Tergal and sternal setae more conspicuous than in female.

Legs: Foreungues much larger than mid- and hindungues, unequal in size, larger one about 1.5 times length of the smaller one and the larger one with submedian blunt-tipped tooth, the smaller one with submedian small tooth.

Genitalia (Fig. 1A-D): Tergum IX with apical area partly sclerotized and divided into two lobes by a shallow V shaped depression with 1-12 fine setae on each lobe. Sternum IX broad and membranous with only the lateral borders sclerotized. Central area with 3-5 fine setae. Gonocoxite (Fig. 1A) about 2.6-3.0 times as long as its breadth at center; lateral and ventral aspects with long setae and scales; dorsal aspect with short fine setae. Basal dorsomesal lobe (BDL) with a tuft of 10-15 stout lanceolate setae with apices crossed to setae on other side of basal dorsomesal lobe; several setae, though not as stout, are also present on the basal dorsomesal lobe (Figs 1 A, D); mesal membrane (MM) with thumb-like lobe with many fine setae (Fig. 1D). Gonostylus (Fig. 1B) about 0.50 times as long as the gonocoxite and reaching the mesal membrane lobe. Outer margin of gonostylus distinctly convex and bearing 1-3 fine setae towards apex; comb of 20 (19-23) teeth, each tooth flat with rounded apices; apical teeth slightly larger than basal teeth. Phallosome (Fig. 1C) ventrally with one pair of large teeth (LT), pointing outwards. The outer apical margin of the phallosome with 18-24 small and regular teeth. Paraproct well developed. 


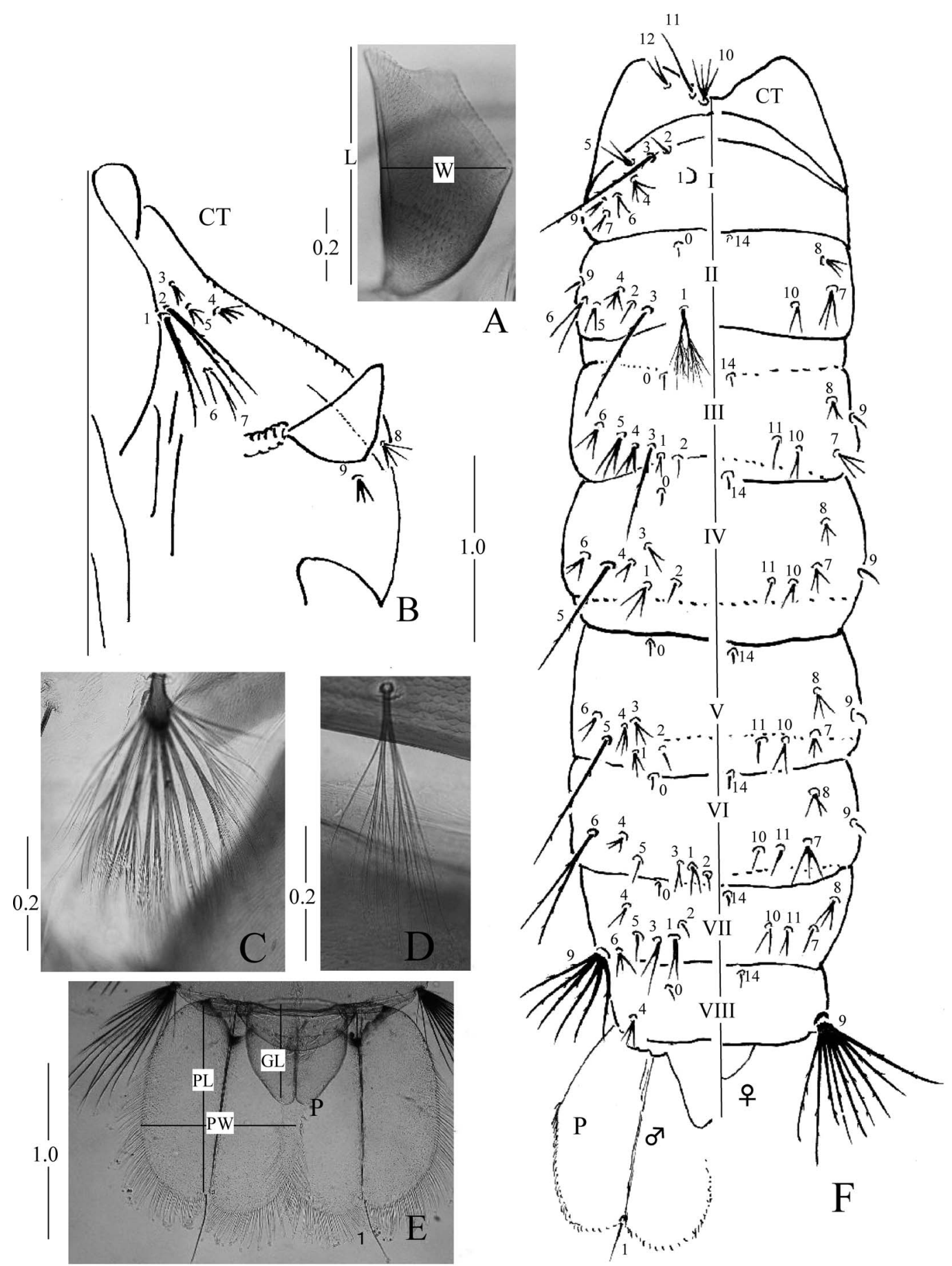

Fig. 2. Pupa of Armigeres (Armigeres) confusus. A, trumpet; B, part of cephalothorax (CT) of exuviae; C, seta 1 of segment I; D, seta 1 of segment II; E, paddle (P) of male (dorsal aspect); F, part of cephalothorax (CT) and abdomen (dorsal and ventral aspects) of excuviae. Scales: mm. 
Table 1. Chaetotaxy of the pupae of Armigeres (Armigeres) confusus

\begin{tabular}{|c|c|c|c|c|c|c|c|c|c|}
\hline \multirow{2}{*}{$\begin{array}{c}\text { Seta } \\
\text { no. }\end{array}$} & \multirow{2}{*}{ Cephalothorax } & \multicolumn{8}{|c|}{ Abdominal segments } \\
\hline & & I & II & III & IV & $\mathrm{V}$ & VI & VII & VIII \\
\hline 0 & - & - & 1 & 1 & 1 & 1 & 1 & 1 & 1 \\
\hline 1 & $2^{*}$ & M & $7-17^{*}$ & $2-4$ & $3-5$ & $3-7$ & $1-4$ & $1-3$ & - \\
\hline 2 & $2 *$ & 1 & 1 & 1 & 1 & 1 & 1 & 1 & - \\
\hline 3 & $3-7$ & $1^{*}$ & $1 *$ & $1^{*}$ & $2-12$ & $3-7$ & $2-6$ & $2-4$ & - \\
\hline 4 & 3,4 & $4-9$ & $4-12$ & $1-6$ & $2-5$ & $3-8$ & $3-6$ & $1-5$ & 3,4 \\
\hline 5 & $3-6$ & $1-3$ & $1-4$ & $1-6$ & $1^{*}$ & $1^{*}$ & $1-3$ & 1 & - \\
\hline 6 & 1 & $2-4$ & 2,3 & 2,3 & $2-4$ & $1-4$ & $1-3^{*}$ & $3-6$ & - \\
\hline 7 & 2,3 & $2-5$ & $3-6$ & $2-5$ & $2-5$ & $5^{-7}$ & $2-5$ & $1(1,2)$ & - \\
\hline 8 & $4-6$ & - & 3,4 & $3-6$ & $3-6$ & $2-6$ & $3-5$ & $2-5$ & - \\
\hline 9 & $2-4$ & 1,2 & 1 & 1 & 1 & 1 & 1 & $2-6^{*}$ & $9-15^{*}$ \\
\hline 10 & $4-8$ & - & $1-3$ & $2-4$ & 2,3 & 2,3 & $1-3$ & $1-3$ & - \\
\hline 11 & 1 & - & - & 1 & 1 & 1 & 1 & $1-3$ & - \\
\hline 12 & $2-5$ & - & - & - & - & - & - & - & - \\
\hline 14 & - & - & 1 & 1 & 1 & 1 & 1 & 1 & 1 \\
\hline
\end{tabular}

* Aciculated; M: fanlike setae with 6-15 main branches.

Seta 8-II present or absent; obsolete and missing setae are shown with a hyphen (-).

Specimens examined: 5 pupal exuviae.

Pupa (Fig. 2A-F, Table 1).

Abdomen, 4.90-5.50 mm. Trumpet, $0.5-0.7 \mathrm{~mm}$. Paddle, $1.10 \mathrm{~mm}$. Integument colored yellow to light brown. Setae light to dark brown. Prominent setae marked with an asterisk.

Cephalothorax: Yellow to light brown pigmentation. Trumpet short, with darker brown pigmentation; index about 2.1. Setae 1, 2-C long with 2 branches.

Abdomen: First 4 abdominal segments slightly darker than remaining segments dorsoanteriorly. Seta 1-I long, fanlike with 6-15 main branches (Fig. 2C); seta 1-II long two main branches, each with about 10 setae (Fig. 2D). Setae 12-I-VII obsolete, 8-II present or absent. Paddle (Fig. 2E): Lightly pigmented except at base, with strong midrib from base to apex and with long marginal filamentous spicules; paddle seta (P-1) single long, 1.6 as long as the length of filamentous spicule. Male genital lobe extending to about 0.4 of paddle, female genital lobe to 0.26 of paddle.

Fourth-instar larva (Fig. 3A-F, Table 2).

Head, 0.8-0.9 mm. Siphon, $0.95 \mathrm{~mm}$. Seta yellow to light brown. Stellate setae and spicules absent. Integument smooth in all segments.

Head (Fig. 3B): Width 1.03-1.13 of length. Light yellow-brown in color except area around mouth and collar which are slightly darker. Mental plate (Fig. 3D) with a strong median tooth and with 5 (5-7) well developed teeth on each side. Seta 1-C small; setae 7, 9-C large with 2, 3 aciculated branches, setae 11, 12-C small 3-7 branched. Antenna; integument smooth, yellow in color, length about 0.37 of head; shaft about the same breadth from base to apex (Fig. 3C), seta 1 at 0.6 from base.

Thorax: Long and prominent pleural setae with barbs. Seta 10-M 5-7 branched, seta 7-T 10-13 branched, seta 9-T 6-9 branched.

Abdomen: Setae 1-III single or double, setae 1-IV, V, VII well developed 2, 3 branched. Seta 13-IV, V 3-5 branched. All these setae more or less aciculate. Seta 5-VIII single with acicula. Comb scales 6-11 in one or two irregular rows, lightly pigmented with rounded and blunt apices; fringe present on apical half. Siphon short and stumpy; index 


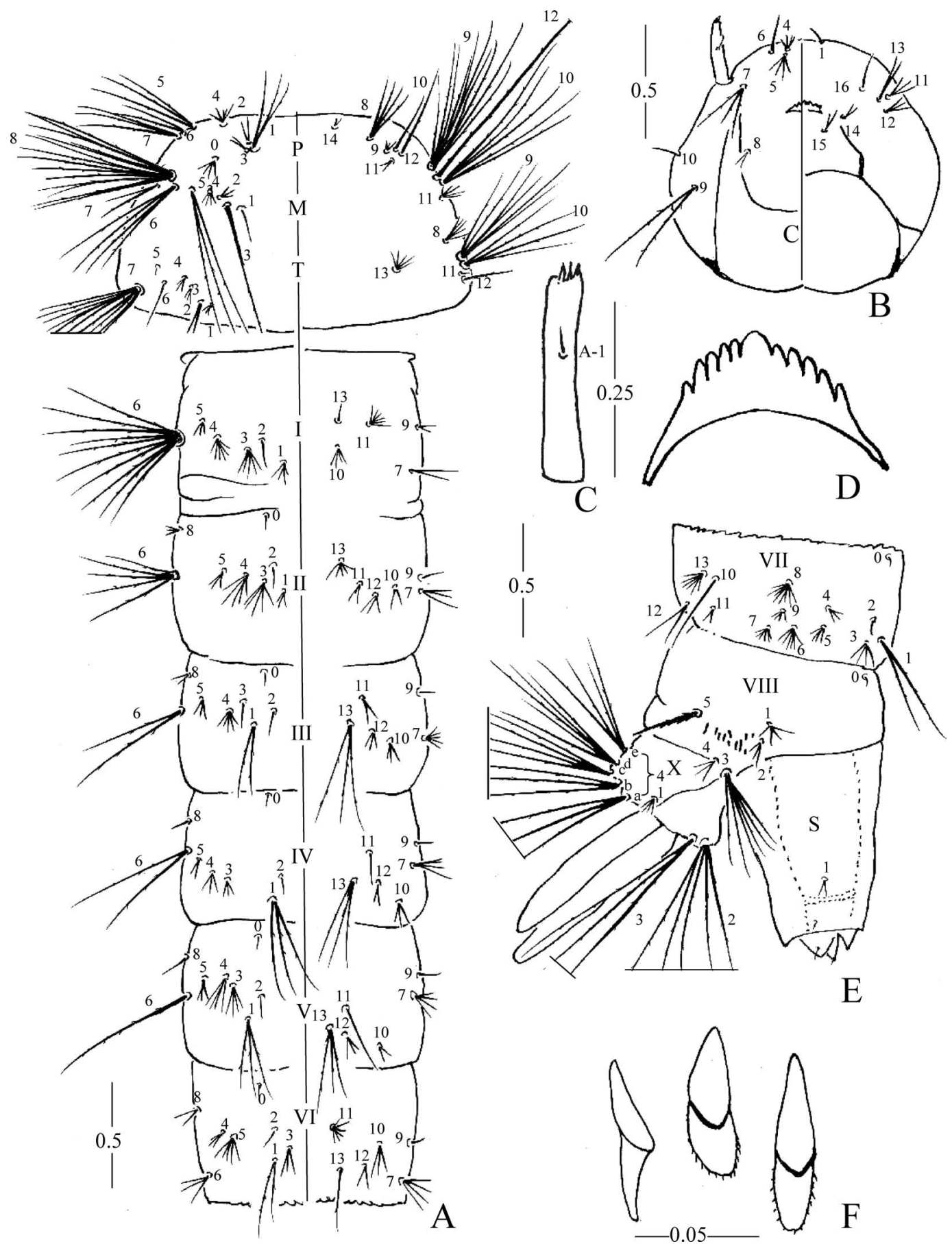

Fig. 3. Fourth-instar larva of Armigeres (Armigeres) confusus. A, thorax and abdominal segments I-VI (dorsal and ventral aspects); B, head (dorsal and ventral aspects) of excuviae; C, antenna; D, dorsomentum (ventral aspect); E, abdominal segments VII, VIII, X and siphon (S) (lateral aspect); F, comb scales. Scales: mm. 
Table 2. Chaetotaxy of the fourth-instar larvae of Armigeres (Armigeres) confusus

\begin{tabular}{|c|c|c|c|c|c|c|c|c|c|c|c|c|}
\hline \multirow{2}{*}{$\begin{array}{c}\text { Seta } \\
\text { no. }\end{array}$} & \multirow{2}{*}{ Head } & \multicolumn{3}{|c|}{ Thorax } & \multicolumn{8}{|c|}{ Abdominal segments } \\
\hline & & $\mathrm{P}$ & $\mathrm{M}$ & $\mathrm{T}$ & I & II & III & IV & $\mathrm{V}$ & VI & VII & VIII \\
\hline 0 & 1 & $4-8$ & - & - & - & 1 & 1 & 1 & 1 & 1 & 1 & 1 \\
\hline 1 & 1 & $2,3^{*}$ & 1 & 2,3 & $3-8$ & $3-7$ & $2(1,2)^{*}$ & $2(2,3)^{*}$ & $2,3^{*}$ & $1,2^{*}$ & $2,3^{*}$ & $6-14$ \\
\hline 2 & - & 1,2 & $3-5$ & $1-3$ & 1 & 1 & 1 & 1 & 1 & 1 & 1 & $3-6$ \\
\hline 3 & - & $2-4$ & $1^{*}$ & $3-5$ & $5-8$ & $5-10$ & $1-3$ & $2(2,3)$ & $4-11$ & $2-5$ & $3-6$ & $6-8 *$ \\
\hline 4 & $4-6$ & $5-8$ & $4-8$ & $3-8$ & $6-12$ & $5-9$ & $4-8$ & 3,4 & $4-6$ & $3-7$ & $3-5$ & $2-4$ \\
\hline 5 & $2-4$ & $3,4^{*}$ & $3-5^{*}$ & 1 & $3-7$ & $3-6$ & $2-6$ & $2-5$ & $3-5$ & $3-5$ & $3-5$ & $1^{*}$ \\
\hline 6 & 1 & $2,3^{*}$ & $4-6^{*}$ & 1,2 & $10-12 *$ & $4-7 *$ & $2^{*}$ & $2^{*}$ & $1^{*}$ & $3-8$ & $6-10$ & $1-X=1-6$ \\
\hline 7 & $2,3 *$ & $3-8 *$ & $2^{*}$ & $10-13^{*}$ & $2-4$ & $2-4$ & $5-7$ & $3-7$ & $4-8$ & 4,5 & $3-6$ & \\
\hline 8 & $2-4$ & $2-6^{*}$ & $11-14^{*}$ & $5-9$ & - & $2-4$ & $2(2,3)$ & 1 & $1(1,2)$ & 1,2 & $8-12$ & $2-X=4(4-6)^{*}$ \\
\hline 9 & $2,3^{*}$ & $2-6$ & $8-13^{*}$ & $6-9 *$ & $2(1,2)$ & 1,2 & 1 & 1 & 1 & 1 & $3-7$ & \\
\hline 10 & 1,2 & 1 & $5-7 *$ & $4-6^{*}$ & $4-6$ & $2-5$ & $2-5$ & $2-4$ & 2,3 & 2,3 & $1-3$ & $3-X=3(3-5)^{*}$ \\
\hline 11 & $3-7$ & $2-4$ & $1-4$ & 1 & $5-10$ & $3-6$ & 1,2 & 1,2 & 1 & $7-11$ & $2-5$ & \\
\hline 12 & $3-7$ & $1^{*}$ & $1^{*}$ & $1(1,2)^{*}$ & $=-$ & $2-4$ & $2-4$ & $2-4$ & $2-4$ & 2,3 & $1-3$ & $4-\mathrm{Xa}=3^{*}$ \\
\hline 13 & 2 & - & - & $5-12$ & 1 & $5-11$ & $3-6 *$ & $3-5^{*}$ & $3-5 *$ & $1,2^{*}$ & $6-13$ & $\mathrm{Xb}=3-4^{*}$ \\
\hline 14 & $1-3$ & $2-4$ & - & - & - & - & - & - & - & - & - & $\mathrm{Xc}=4-6^{*}$ \\
\hline 15 & 2,3 & - & - & - & - & - & - & - & - & - & - & $\mathrm{Xd}=5-8^{*}$ \\
\hline 16 & 1,2 & - & - & - & - & - & - & - & - & - & - & $\mathrm{Xe}=4-8^{*}$ \\
\hline
\end{tabular}

* Aciculated; obsolete and missing setae are shown with a hyphen (-).

Specimens examined: 5 fourth-stage larvae.

about 1.4, pigmented brown; seta 1-S 2, 3 branched, inconspicuous, arising about 0.22 from apical end. Anal segment: Saddle incomplete, pigmented brown. Gills long, with bluntly rounded apices.

Remarks. Armigeres confusus was originally described from 7 males and 4 females, which were collected by Moulton in Kuching in Sarawak, 1914 (Edwards, 1915). The original description was very brief. Brug (1931) and Bonne-Wepster and Brug (1937) redescribed briefly the adult and larva of this species based on specimens collected from Indonesia (Kalimantan and Sumatra). Macdonald (1957) recorded this species from Selangor, Peninsular Malaysia.

We (Toma and Miyagi) examined the type specimens (syntype: Sarawak, Kuching 19-20 II, 1914-287, ऽ , 1914-409 우, J. C.; Moulton) of Ar. confusus in the Natural History Museum of London. It is easily identified by the entirely white abdominal sterna I-VI and entirely black VII in both sexes. On the basis of male genitalia, Ar. confusus somewhat resembles Ar. setifer from the Philippines (Delfinado, 1966) and Sarawak (Toma et al., 2007), but is characterized by a prominent basal dorsomesal lobe (BDL) with a tuft of many strong lanceolate setae as well as a mesal membrane lobe (MM) with many fine scattered setae. The pupa and larva of Ar. confusus can also be distinguished from other species treated in this paper as shown in the keys.

Biological Notes. Immatures of Ar. confusus were found in coconut fruits associated with Ar. malayi, Ar. moultoni, Ar. setifer and Ar. jugraensis. During the mosquito collection, several oviposition traps (artificial containers) with polluted water were placed in the forest of Matang National Park, Kuching. Armigeres confusus may be primarily a tree-hole breeder in the natural forest, but due to human activities, such as deforestation and urbanization, it has expanded its habitat to fallen coconut fruits that have an opening and artificial containers with polluted water in cultivated areas at coastal coconut plantations. The females of Ar. confusus readily bite humans at night. Several females were collected from the coconut farm at night and during the daytime from 
shaded areas at Matang National Park by Okazawa and Miyagi in September 2006.

Distribution. Malaysia: East (Sarawak) and Peninsular (Selangor). Also reported from Indonesia (Sumatra).

\section{Armigeres (Armigeres) jugraensis (Leicester), 1908}

(Figs. 4-6, Tables 3, 4)

Desvoidya jugraensis Leicester, 1908. Stud. Inst. Med. Res. F. M. S. 3: 77 (우, ○7). Type locality: Ampang Jungle, Kuala Lumpur (Selangor), Malaysia.

Armigeres (Armigeres) jugraensis (Leicester, 1908): Edwards, 1917. Bull. Entomol. Res. 7: 208 (key); Thurman, 1959. Univ. Maryland Agr. Exp. Sta. Bull. A-100: 86 (ㅈ*).

Specimens Examined. The following specimens were collected as larval and pupal stages from fallen coconut fruits in a coconut farm of Asajaya in August and September 2005 and 2006, and Sampadi in September 2006. 1万', 1우 (050924-4) on pin with L, P (84, 96) on slides; 1우, 1万 (050924-5) on pin with L, P (84, 96) on slides; $1 \sigma^{\nearrow}(060829-2)$ with (G6) and L, P (66); 1우 (060829-2) with L, P (32); 10 (060911-7) with L, P (256) and (G16); 10 (060911-7) with (G17); 1우 (060911-7) with L, P (258) and (G18); 1우 (060911-7) with L, P

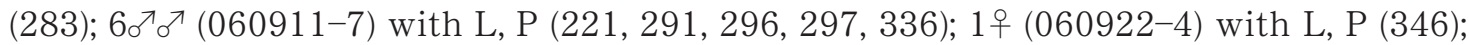

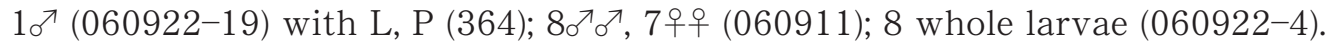

\section{Description.}

Female (Fig. 4G-I).

Wing, 4.0-4.1 mm. Proboscis, $3.7 \mathrm{~mm}$. Forefemur, 2.3-2.5 mm. Abdomen, 3.8-3.9 $\mathrm{mm}$.

Head: Vertex covered with flat, broad, dark scales entirely. Erect scales all dark, forked and restricted to occiput region of the head. Sides of head mostly covered with white scales. Anntena pilose approximately $2.3 \mathrm{~mm}$ long.

Thorax: Scutum with a few narrow, curved white scales on anterior pronotum. Prescutellar area without white scales. Scutellum covered with flat, dark brown scales, without a patch of light brown broad scales on mid lobe. 6-8 conspicuous setae arising on each lobe.

Legs: Fore and mid femora with a line of white scales on ventral side to knee; hind femur with a broad line of white scales on outer aspect to knee. Rest of legs covered with dark scales. Foreungues slightly larger than midungues, equal in size, both with tapering submedian tooth.

Abdomen (Fig. 4G-I): Terga I-VII dark scaled on dorsal aspect; tergum VIII mostly dark with a few white scales basally. Sterna II-VII entirely white scaled without apical dark bands and VIII mostly dark scaled.

Wing: Cell $\mathrm{R}_{2} 1.25$ times the length of its stem.

Male (Fig. 4A-F).

Wing, 3.5-3.7 mm. Proboscis, $2.30 \mathrm{~mm}$. Palpus, $2.50 \mathrm{~mm}$. Forefemur, 2.0-2.5 mm. Resembles the female except in the following characters.

Head: Palpus approximately 1.14 times the length of the proboscis. Antenna 1.85 mm long.

Thorax (Fig. 4J): Border of scales around scutum much broader than in female and extending further back over wing roots. Patch of white scales in prescutellar area also larger. Median scutellum with a large patch of white scales. Antepronotum and 

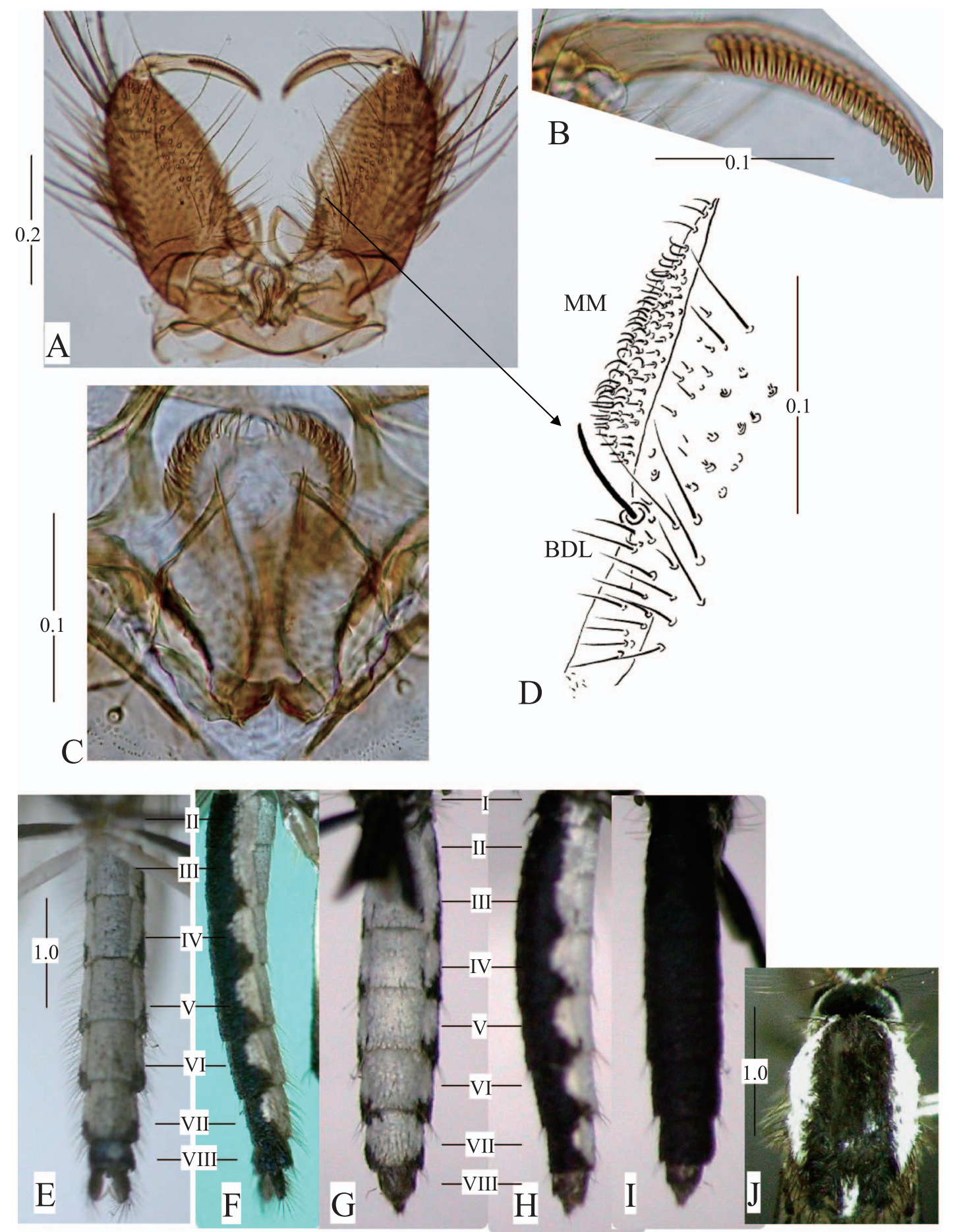

Fig. 4. Adult male (A-F and $\mathrm{J}$ ) and female (G-I) of Armigeres (Armigeres) jugraensis. A, structures of genitalia (ventral aspect); B, gonostylus; C, phallosome (ventral aspect); D, basal dorsomesal lobe (BDL) and mesal membrane (MM); $\mathrm{E}$ and $\mathrm{G}$ abdominal sterna (ventral aspect); $\mathrm{F}$ and $\mathrm{H}$ abdomen (lateral aspect); I, abdominal terga (dorsal aspect); J, scutum and scutellum (dorsal aspect). Scales: $\mathrm{mm}$. 


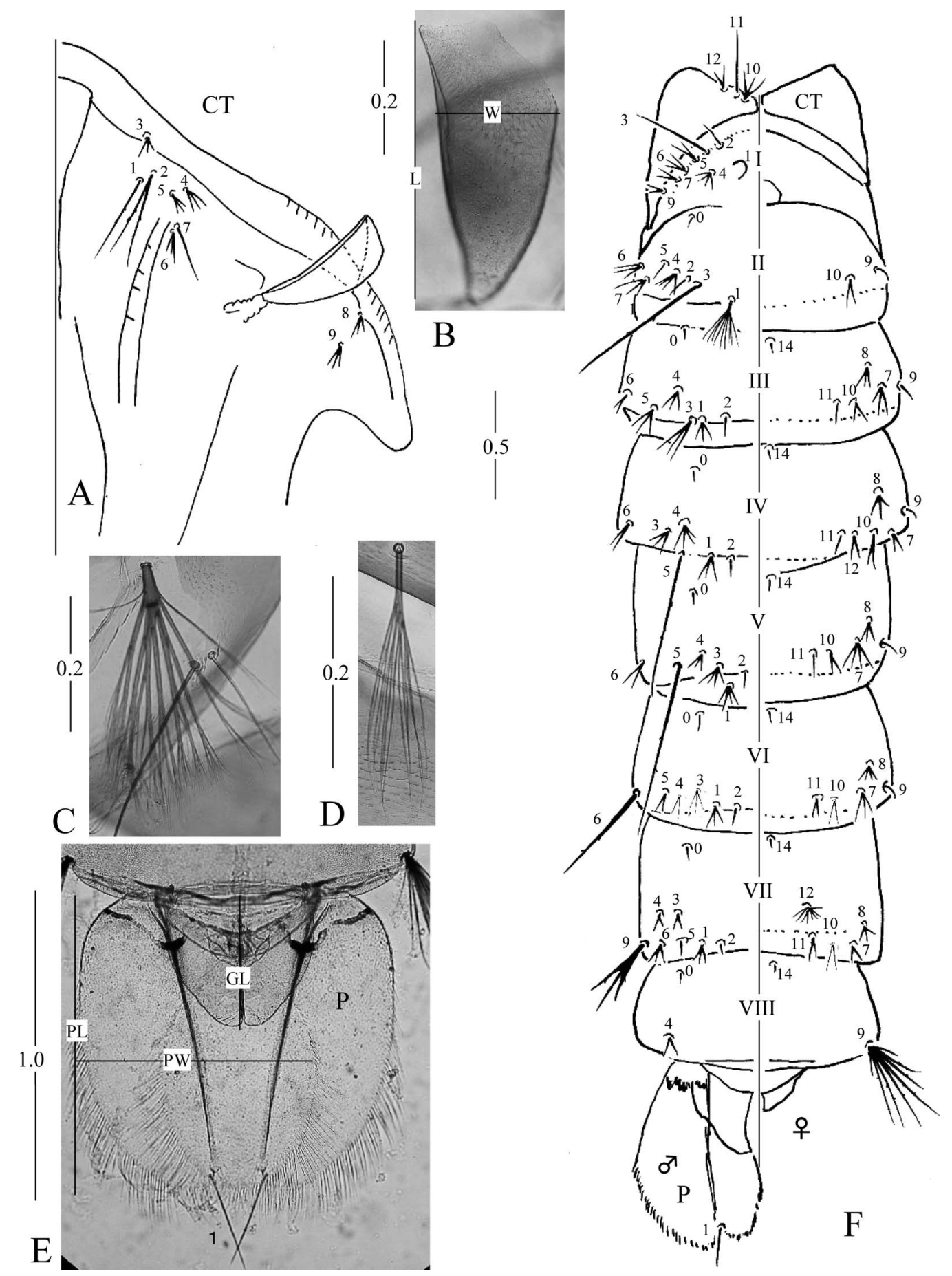

Fig. 5. Pupa of Armigeres (Armigeres) jugraensis. A, part of cephalothorax CT) of exuviae; B, trumpet; C, seta 1 of segment I; D, seta 1 of segment II; E, paddle (P) of male (dorsal aspect); F, part of cephalothorax (CT) and abdomen (dorsal and ventral aspects) of excuviae. Scales: mm. 
postpronotum with numerous narrow pale scales entirely, pale scales in lower half are slightly broader.

Abdomen (Fig. 4E, F): Terga I-VIII all dark, without white scales. Sterna II-VII entirely white, VIII dark with a few white scales (Fig. 4E, F). Tergal and sternal setae more conspicuous than in female.

Legs: Foreungues larger than the other, unequal in size, the larger one about 1.5 times the length of the smaller one, both with a blunt-tipped submedian tooth. Mindungues equal in size, both with a tapering submedian tooth. Hindungues equal in size, simple.

Genitalia (Fig. 4A-D): Tergum IX with apical area partly sclerotized and divided into two lobes by a shallow $\mathrm{V}$ shaped depression with 10-12 fine setae on each lobe. Sternum IX broad and membranous with only the lateral borders sclerotized. Central area with 3-5 fine setae. Terminalia bulbous, gonocoxite about 2.0 times as long as its breadth at center; lateral and ventral aspects with long setae and scales; dorsal aspect with short fine setae. Basal dorsomesal lobe (BDL) with one well developed lanceolate seta with several well developed setae; mesal membrane (MM) convex gradually with many fine spine like setae marginally. Gonostylus (Fig. 4B) short, about 0.53 times as long as the gonocoxite; outer margin of gonostylus convex and sometimes bearing 1-2 fine setae towards apex; comb of 18-21 teeth, each tooth flat with rounded apices; apical teeth slightly larger than basal teeth. Phallosome (Fig. 4C) expanded, like a bulb; outer apical margin of the phallosome with 16-18 small and regular teeth. Paraproct well developed.

Pupa (Fig. 5A-F, Table 3).

Abdomen, 4.12-5.13 mm. Trumpet, 0.51-0.63 mm. Paddle, $0.88 \mathrm{~mm}$. Integument colored yellow to light brown. Setae light to dark brown.

Cephalothorax: Trumpet (Fig. 5B) long, with darker brown pigmentation; index 2.52.7. Seta 1, 2-C long with 1, 2 branches.

Abdomen: First 4 abdominal segments slightly darker than remaining segments. Segment 1-I long fanlike with 6-11 main branches (Fig. 5C), seta 1-II long with 10-25

Table 3. Chaetotaxy of the pupae of Armigeres (Armigeres) jugraensis

\begin{tabular}{|c|c|c|c|c|c|c|c|c|c|}
\hline \multirow{2}{*}{$\begin{array}{c}\text { Seta } \\
\text { no. }\end{array}$} & \multirow{2}{*}{ Cephalothorax } & \multicolumn{8}{|c|}{ Abdominal segments } \\
\hline & & I & II & III & IV & $\mathrm{V}$ & VI & VII & VIII \\
\hline 0 & - & - & 1 & 1 & 1 & 1 & 1 & 1 & 1 \\
\hline 1 & $1,2^{*}$ & M & $10-25$ & $3-5$ & $3-5$ & $3-6$ & $2-4$ & $1-4$ & - \\
\hline 2 & $2(1,2)^{*}$ & 1 & $1(1,2)$ & $1(1-3)$ & $1(1,2)$ & $1(1,2)$ & $1(1,2)$ & $1-3$ & - \\
\hline 3 & $2-6$ & 1 & $1 *$ & $1-6$ & $3-7$ & $4-7$ & $3-5$ & $2-5$ & - \\
\hline 4 & $3-6$ & $4-12$ & $4-10$ & $3-5$ & $3-6$ & $3-7$ & $2-4$ & $1-4$ & $1-3$ \\
\hline 5 & $2-6$ & $2-4$ & $1(1-3)$ & $2-6$ & $1 *$ & $1^{*}$ & $1-3$ & $1-3$ & - \\
\hline 6 & $1-5$ & $3-6$ & 3-6 & $2-4$ & $1-3$ & $1-4$ & $1(1,2)^{*}$ & $2-5$ & - \\
\hline 7 & 1 & $2-4$ & $2-8$ & $2-5$ & $2-4$ & $4-7$ & $2-4$ & $2-4$ & - \\
\hline 8 & $2-6$ & - & - & $3-7$ & $2-5$ & $3-6$ & $4-8$ & $3-7$ & - \\
\hline 9 & $2-4$ & 2,3 & 1 & 1 & 1 & 1 & 1 & $2-4^{*}$ & $6-13^{*}$ \\
\hline 10 & $4-7$ & - & $2-4$ & $2-4$ & $2-4$ & $1-3$ & $2-4$ & $2-4$ & - \\
\hline 11 & 1 & - & - & 1 & $1(1,2)$ & 1 & 1,2 & $1-3$ & - \\
\hline 12 & $2-5$ & - & - & - & 2 & - & - & 7,8 & - \\
\hline 14 & - & - & - & 1 & 1 & 1 & 1 & 1 & 1 \\
\hline
\end{tabular}

* Aciculated; M: fanlike setae with 6-11 main branches.

Seta 12-VII usually obsolete; obsolete and missing setae are shown with a hyphen (-).

Specimens examined: 5pupal exuviae. 


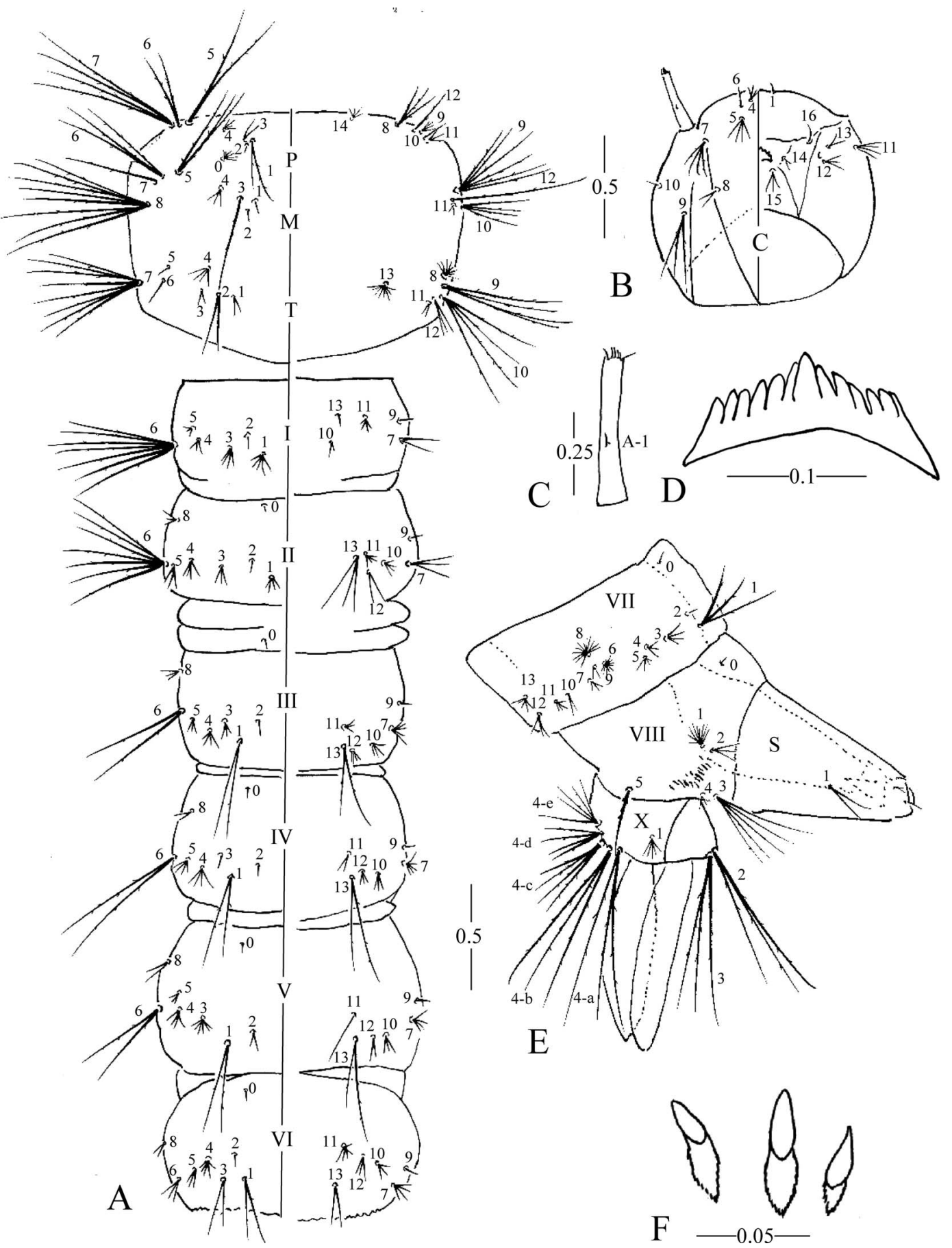

Fig. 6. Fourth-instar larva of Armigeres (Armigeres) jugraensis. A, thorax and abdominal segments I-VI (dorsal and ventral aspects); B, head (dorsal and ventral aspects) of exuviae; C, antenna; D, dorsomentum (ventral aspect); E, abdominal segments VII, VIII, X and siphon (S) (lateral aspect); F, comb scales. Scales: $\mathrm{mm}$. 
Table 4. Chaetotaxy of the fourth-instar larvae of Armigeres (Armigeres) jugraensis

\begin{tabular}{|c|c|c|c|c|c|c|c|c|c|c|c|c|}
\hline \multirow{2}{*}{$\begin{array}{c}\text { Seta } \\
\text { no. }\end{array}$} & \multirow{2}{*}{ Head } & \multicolumn{3}{|c|}{ Thorax } & \multicolumn{8}{|c|}{ Abdominal segments } \\
\hline & & $\mathrm{P}$ & M & $\mathrm{T}$ & I & II & III & IV & $\mathrm{V}$ & VI & VII & VIII \\
\hline 0 & - & $5-8$ & - & - & - & 1 & 1 & 1 & 1 & 1 & 1 & 1 \\
\hline 1 & 1 & $2^{*}$ & 1 & $2-4$ & $5-8$ & $3-8$ & $2^{*}$ & $2^{*}$ & $2^{*}$ & $2(2,3)^{*}$ & $2,3^{*}$ & $9-17$ \\
\hline 2 & - & 1,2 & $1-3$ & 2,3 & $1(1,2)$ & 1 & 1 & 1 & $1(1,2)$ & 1 & $1(1,2)$ & $2-4$ \\
\hline 3 & - & $2-4$ & $1,2^{*}$ & 2,3 & $4-9$ & $3-7$ & $1-3$ & 1,2 & $6-12$ & $2,3^{*}$ & $4-12$ & $5-10$ \\
\hline 4 & $6-9$ & $4-7$ & $3-7$ & $4-9$ & $3-10$ & $4-8$ & $4-8$ & $4-7$ & $4-7$ & $5-8$ & $3-6$ & $2-4$ \\
\hline 5 & $2-8$ & $2,3^{*}$ & $3^{*}$ & 1 & $2-12$ & $3-5$ & 3,4 & $3-6$ & $3-5$ & $3-6$ & $4-7$ & $1^{*}$ \\
\hline 6 & 1 & $1,2^{*}$ & $3-5^{*}$ & 1,2 & $7-11^{*}$ & $4-9 *$ & $2^{*}$ & $2(1,2)^{*}$ & $2(1,2)^{*}$ & $3-9$ & $8-11$ & $1-X=4-6$ \\
\hline 7 & $3,4^{*}$ & $3-7^{*}$ & $1,2^{*}$ & $6-9 *$ & $2-4^{*}$ & $2-4^{*}$ & $5-10$ & $5-8$ & $5-8$ & $3-9$ & $2-6$ & \\
\hline 8 & 2,3 & $2-4^{*}$ & $8-10^{*}$ & $8-15$ & - & $2-4$ & $2-4$ & $1-3$ & $2(1,2)$ & $2-4$ & $12-19$ & $2-X=3,4^{*}$ \\
\hline 9 & $2-8^{*}$ & $4-7$ & $5-10^{*}$ & $4,5^{*}$ & $1-3$ & 1 & 1 & 1 & 1 & 1 & $2-9$ & \\
\hline 10 & 1,2 & 1 & $3-5^{*}$ & $4,5^{*}$ & $2-5$ & $3-5$ & $3-6$ & $2-5$ & $2-4$ & $1-5$ & $2-10$ & $3-\mathrm{X}=3^{*}$ \\
\hline 11 & $3-8$ & $2-5$ & 2,3 & $2-4$ & $4-8$ & $3-7$ & $1-3$ & $2(1-3)$ & $1(1,2)$ & $5-8$ & $3-5$ & \\
\hline 12 & $3-6$ & $1^{*}$ & $1(1,2)^{*}$ & $1-3$ & - & $2-4$ & $1-6$ & $2-4$ & 2,3 & $2-4$ & $1-4$ & $4-\mathrm{Xa}=3^{*}$ \\
\hline 13 & $2-4$ & - & - & $8-13$ & 1,2 & $3-14$ & $2(2,3)^{*}$ & $2^{*}$ & $2^{*}$ & 2,3 & $5-18$ & $\mathrm{Xb}=3,4^{*}$ \\
\hline 14 & $2(1-3)$ & $3-6$ & - & - & - & - & - & - & - & - & - & $\mathrm{Xc}=3-5^{*}$ \\
\hline 15 & $2-5$ & - & - & - & - & - & - & - & - & - & - & $\mathrm{Xd}=4-7^{*}$ \\
\hline 16 & $1(1,2)$ & - & - & - & - & - & - & - & - & - & - & $\mathrm{Xe}=5-7^{*}$ \\
\hline
\end{tabular}

* Aciculated; obsolete and missing setae are shown with a hyphen (-).

Specimens examined: 7 fourth-stage larvae.

apical branches (Fig. 5D). Seta 6-VI long, aciculate, usually single; seta 9-VII long, aciculate, 2-4 branched; seta 9-VIII long, aciculate, 6-13 branched; seta 8-II obsolete, 12VII usually obsolete except one of the examined specimens 7,8 branched. Paddle. Lightly pigmented except at base, with strong midrib from base to apex and with long marginal filamentous spicules; paddle seta $(\mathrm{P}-1)$ single long, 2.08 times as long as the length of the longest filamentous spicule. Male genital lobe extending to about 0.47 times the paddle, female genital lobe to 0.26 times the paddle.

Fourth-instar larva (Fig. 6A-F, Table 4).

Head, 0.85-0.90 mm. Siphon, $0.89 \mathrm{~mm}$. Stellate setae and spicules absent. Integument smooth.

Head: Width same as or about 1.1 times the length. Light yellow-brown in color except area around mouth and collar which are slightly darker. Mental plate with a strong median trilobed tooth and with $6\left(5^{-7}\right)$ well developed teeth on each side. Head seta 1 , single, small, tapering and curved inwards, seta 6 single, seta 73 , 4 branched, seta 9 well developed with 2-8 branchs, seta 11 small with 2-8 branches. Antenna length about 0.30 times the head; shaft about the same breadth from base to apex. Seta 1-A inserted at basal 0.45 length of antenna.

Thorax: Seta 1-P long, 2 branched, seta 3-P 2-4 branched. Setae 9-12-M, -T arising from a common tubercle. All these setae long and aciculate.

Abdomen: Comb scales 11-20 in one or two irregular rows, lightly pigmented and pointed apically and finely fringed. Siphon short and stumpy, pigmented brown; index 1.8; seta 1 usually bifid, inconspicuous, inserted at apical about 0.29 length of siphon. Gills long, with bluntly rounded apices; ventral pair slightly longer than dorsal pair.

Remarks. Armigeres jugraensis was originally described from Kuala Lumpur, Malaysia by Leicester (1908). Edwards (1917) provided taxonomical notes for this species including a key to the adults of the subgenus Armigeres found in Malaysia. Thurman (1959) 
redescribed the adults and illustrated the male genitalia of this species based on specimens collected from Chiang Mai, Thailand. The specimens examined from Kuching are identical with the male genitalia illustrated by Thurman (1959). This species is characterized by the abdominal sterna II-VII being entirely white scaled without apical dark bands; sternum VIII mostly dark scaled and phallosome short, expanded roundly at apex, margin crenulated with 16-18 small coarse teeth; basal dorsomesal lobe with only one stout seta and mesal membrane with many fine spine-like setae.

Biological Notes. The females bite humans inside sheds during the daytime and in the forest at dusk.

Distribution. Malaysia: East (Sarawak) and Peninsular (Selangor). Also reported from Indonesia (Sumatra and Java) and Thailand (Chiang Mai).

\section{Armigeres (Armigeres) moultoni Edwards, 1914}

(Figs 7-9, Tables 5, 6)

Armigeres moultoni Edwards, 1914, Bull. Entomol. Res. 5: 125 (ऽㄱ, 우).

Armigeres (Armigeres) moultoni Edwards: Edwards, 1917, Bull. Entomol. Res. 7: 203 (key).

Specimens Examined. The following specimens were collected as larval and pupal stages from fallen coconut fruits at Sampadi, Kuching, Sarawak in September 2005 and reared to adults. $1 \sigma^{\text {T }}(050915-2)$ on pin with $\mathrm{L}$ and P exuviae mounted on slide L, P (12) and genitalia (G) on another slide (G67); 10 (050920-6) on pin with slides L, P (56) and (G65);

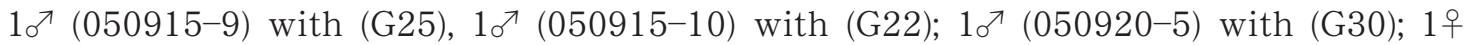
(050914-26) with L, P (21), (050915-4) with L, P (83); 1우 (050915-9) with P (79); 1 우 (050920-12) with L, P (81); 1 (050920-15) with L, P (52); 4 (050915) with L, P (13, 22, 26, 70); 18 whole larvae on slides.

\section{Description.}

Female (Fig. $7 \mathrm{H}-\mathrm{J})$.

Wing, 3.50-3.75 mm. Proboscis, 2.25-2.50 mm. Forefemur, 2.50-2.60 mm. Abdomen, 3.55-3.75 mm.

Head: Vertex covered with flat, broad, dark scales, except for small central patch of pale scales. Erect scales all dark, forked and restricted to occiput region of the head. Sides of head mostly covered with white scales. Anntena pilose, 2.0-2.35 mm.

Thorax: Integument brown to dark brown. Scutum densely covered with narrow, curved, dark brown scales. Lateral scutal fosal, antealar and supuraalar areas and paratergite without white scales. Center of prescutellar area black without white scales. Scutellum covered with flat, dark brown scales, without white scales on each lobe; conspicuous 5-8 setae arising on each lobe. Upper half of postpronotum covered with narrow small brown scales; lower half with broad white scales; row of 4-6 brownish setae along posterior border. Postspiracular area with patch of white scales and $3-4$ pale setae. Mesokatepisterum with two large, upper patch of white scales with 2 upper and one lower well developed dark setae and lower patches of white scales with one upper brown seta, 4-6 dark setae on prealar knob. Upper mesepimeron with a large patch of white scales; single lower seta and a dense patch of upper mesepimeral setae present.

Legs: Fore coxa covered with white scales; mid and hind coxae with a patch of white scales on anterior side and some coxal scales on anterior side. Fore and mid femur 

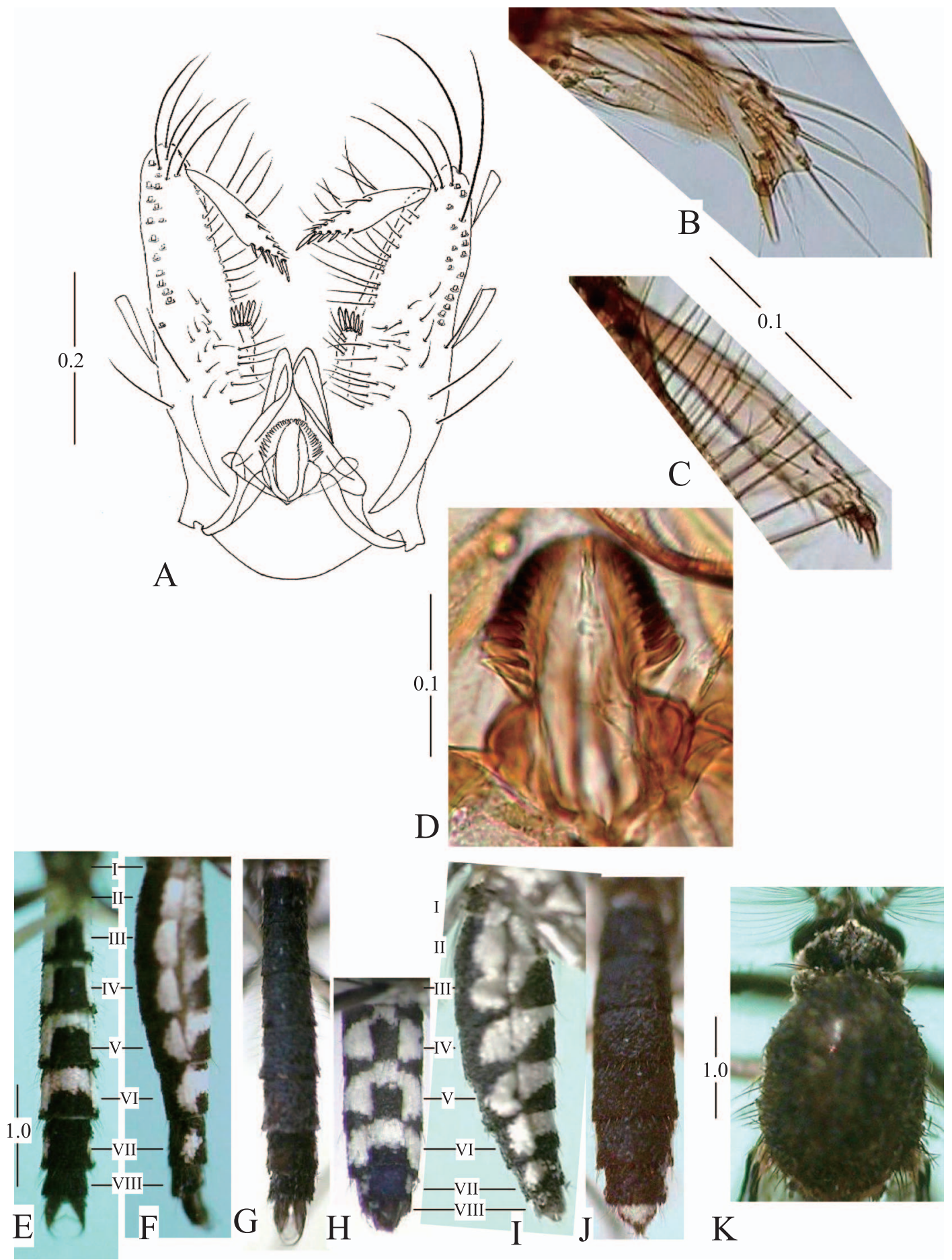

K

Fig. 7. Adult male (A-G and $\mathrm{K}$ ) and female (H-J) of Armigeres (Armigeres) moultoni. A, structures of genitalia (ventral aspect); B, gonostylus; C, gonostylus (different aspect); D, phallosome (ventral aspect); $\mathrm{E}$ and $\mathrm{H}$, abdominal sterna (ventral aspect); $\mathrm{F}$ and I, abdomen (lateral aspect); $\mathrm{G}$ and J, abdominal terga (dorsal aspect); K, scutum (dorsal aspect). Scales: mm. 
with a line of white scales on ventral side to knee; hind femur with a broad line of white scales on outer aspect to knee; the apical fifth black on both outer and under sides. Rest of legs covered with dark scales. Foreungues slightly larger than midungues, unequal in size, both with a submedian tapering tooth.

Wing: Dark scales. Cell $\mathrm{R}_{2}$ about 1.53 times the length of its stem.

Abdomen (Fig. 7H-J): Terga I-VII dark scaled on dorsal aspect, with usual lateral patches of white scales; tergum VIII basal $2 / 3$ with white scales, rest dark scaled. Sterna I, II white entirely; sterna III-VI black with white basal scale band, the band broad on sterna V and VI; sterna VII, VIII entirely dark scaled.

Male (Fig. 7A-G, K).

Wing, $3.50 \mathrm{~mm}$. Proboscis, $2.50 \mathrm{~mm}$. Palpus, 2.50-2.67 mm. Forefemur, 2.25-2.43 $\mathrm{mm}$. Antenna $2.17 \mathrm{~mm}$. Resembles female except in the following characters.

Thorax: Border of scales around scutum black without conspicuous white scales. Prescutellar area and median and lateral scutellar lobes black without white scales. Coloration of sterna same as the female.

Abdomen (Fig. 7E-G): Sternum II entirely white. Sterna III-VI black with white basal band. Sterna VII and VIII entirely dark.

Legs: Ungues of foreleg much larger than that of female. Foreungues unequal in size, the larger about 1.7 times the length of the smaller one, the larger one with a submedian blunt-tipped tooth, the smaller one simple. Midungues small, subequal in size both with a submedian tooth.

Genitalia (Fig. 7A-D): Tergum IX with apical area partly sclerotized and divided into two lobes by a V shaped depression with 5-10 fine setae on each lobe. Sternite IX broad and membranous with only the lateral borders sclerotized, central area with 6-10 fine setae. Gonocoxite tapered gradually, triangular in shape, about 3.0-3.6 times as long as its breadth at center; outer lateral margin with many long curved setae; dorsal aspect with short fine setae. Basal dorsomesal lobe with a tuft of $5(4,5)$ stout lanceolate setae with fine setae. Mesal membrane with a row of many filamentous setae, the setae of apical margin longer than basal ones. Gonostylus inserted on the subapical inner margin of gonocoxite. Length of gonostylus short, broad in the middle, about 0.38 times as long as the gonocoxite; comb of 4-6 teeth, each tooth pointed at apex; mingled with 1-3 fine setae; apical teeth slightly larger than the others. Different aspect of the apical part of the gonostylus shown in Fig. 7B, C. Phallosome (Fig. 7D) with about 20 small and regular teeth on apical margin on each side, the basal 1-6 teeth longer than the other apical teeth. Paraproct well developed.

Pupa (Fig. 8A-F, Table 5).

Abdomen, $4.70 \mathrm{~mm}$. Trumpet, $0.53 \mathrm{~mm}$. Paddle, $1.02 \mathrm{~mm}$. Integument colored yellow to light brown. Setae light to dark brown.

Cephalothorax: Yellow to light brown pigmentation. Trumpet (Fig. 8B) short, with darker brown pigmentation; index 1.9. Seta 1-C large 2-4 branched, seta 2-C large, 2-5 branched.

Abdomen: Setae 1-I, II well developed, many branches (Fig. 8C, D). Setae 3-II, 3, 6-III, 5, 6-IV, V long, aciculate, 6-VI 2-4, 9-VII 5-9, 9-VIII 9-17 long, aciculate branched. Paddle. Index 1.28; midrib clearly from base to near apex and with marginal filamentous spicules; paddle seta (P-1) absent. Male genital lobe extending to about 0.48 times the paddle, female genital lobe to 0.26 times the paddle. 


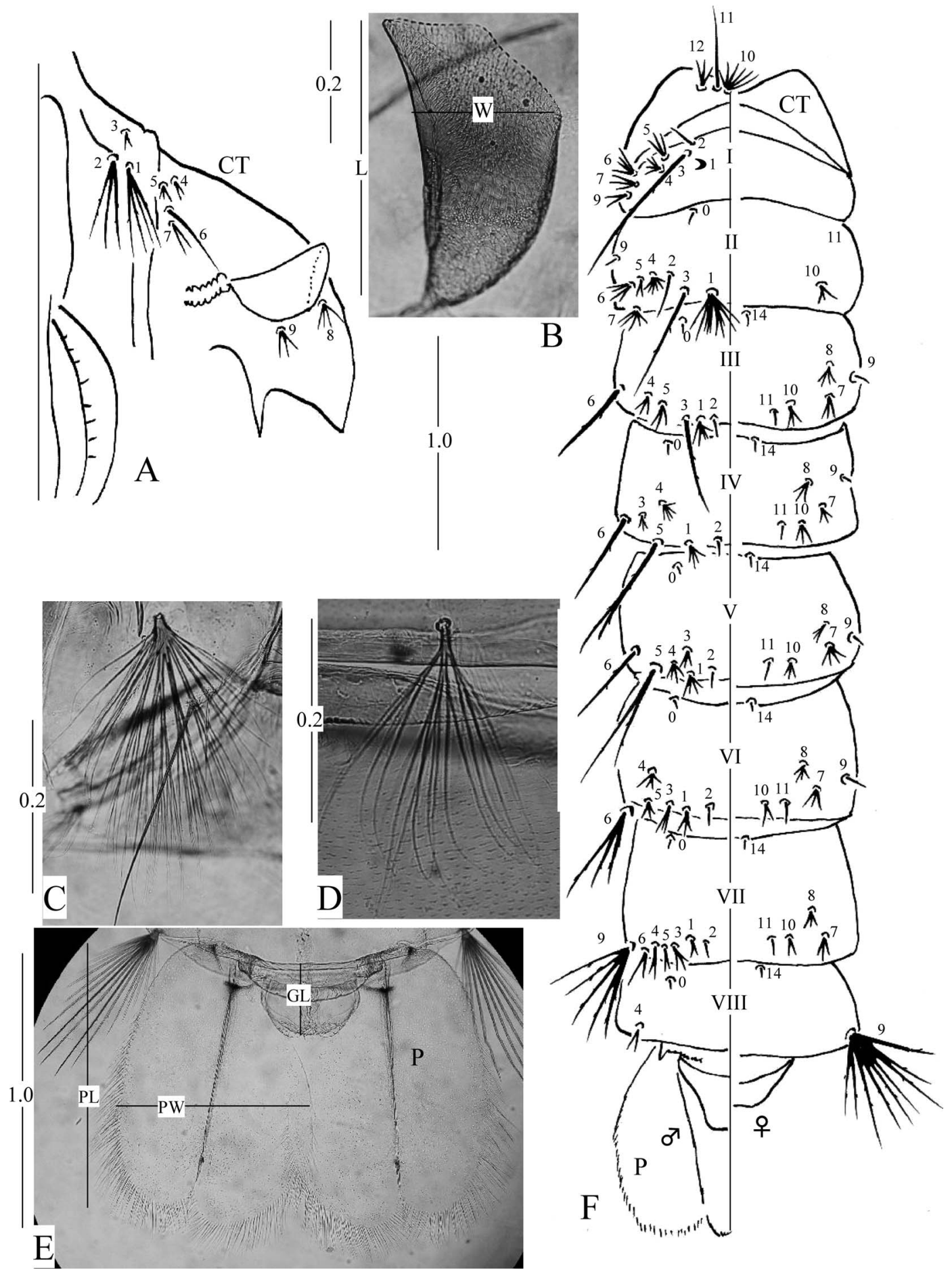

Fig. 8. Pupa of Armigeres (Armigeres) moultoni. A, part of cephalothorax (CT) of exuviae; B, trumpet; C, seta 1 of segment I; D, seta 1 of segment II; E, paddle (P) of male (dorsal aspect); F, part of cephalothorax (CT) and abdomen (dorsal and ventral aspects) of excuviae. Scales: mm. 
Table 5. Chaetotaxy of the pupae of Armigeres (Armigeres) moultoni

\begin{tabular}{|c|c|c|c|c|c|c|c|c|c|}
\hline \multirow{2}{*}{$\begin{array}{c}\text { Seta } \\
\text { no. }\end{array}$} & \multirow{2}{*}{ Cephalothorax } & \multicolumn{8}{|c|}{ Abdominal segments } \\
\hline & & I & II & III & IV & $\mathrm{V}$ & VI & VII & VIII \\
\hline 0 & - & - & 1 & 1 & 1 & 1 & 1 & 1 & 1 \\
\hline 1 & $2-4^{*}$ & M & $8-19 *$ & $3-7$ & $4-7$ & $2-7$ & $3-5$ & $1-5$ & - \\
\hline 2 & $2-6^{*}$ & $1(1,2)$ & 1 & 1 & 1 & 1 & 1 & 1 & - \\
\hline 3 & $2-5$ & $1^{*}$ & $1^{*}$ & $1^{*}$ & $2-7$ & $3-9$ & $3-6$ & $2-4$ & - \\
\hline 4 & $2-6$ & $4-12$ & $6-13$ & $3-6$ & $4-8$ & $5-9$ & $3-7$ & $2-5$ & $2-5$ \\
\hline 5 & $3-8$ & $2-5$ & $2-5$ & $3-7$ & $1-3^{*}$ & $1-5^{*}$ & $1-3$ & $1-3$ & - \\
\hline 6 & 1 & $4-7$ & $4-9$ & $1,2^{*}$ & $1(1-4)^{*}$ & $1,2^{*}$ & $2-4^{*}$ & $1-4$ & - \\
\hline 7 & $2-5$ & $2-5$ & $4-8$ & $3-5$ & $2-5$ & $4-9$ & $3-6$ & $2-4$ & - \\
\hline 8 & $4-9$ & - & - & $3-6$ & $3-5$ & $2-4$ & $3-5$ & $2-6$ & - \\
\hline 9 & $3-7$ & $2-5$ & 1 & 1 & $1(1,2)$ & 1 & 1 & $5-9 *$ & $9-17 * *$ \\
\hline 10 & $6-13$ & - & $2-5$ & $3-6$ & $2-4$ & $1-3$ & $1-5$ & $1-3$ & - \\
\hline 11 & 1 & - & - & 1 & 1 & 1 & 1 & $1-3$ & - \\
\hline 12 & $2-4$ & - & - & - & - & - & - & - & - \\
\hline 14 & - & - & - & 1 & 1 & 1 & 1 & 1 & 1 \\
\hline
\end{tabular}

* Aciculated; M: fanlike setae with 6-12 main branches.

Obsorate and missing setae are shown with a hyphen (-).

Specimens examined: 6 pupal exuviae.

Fourth-instar larva (Fig 9A-F, Table 6).

Head, 0.75-0.78 mm. Siphon, $0.63 \mathrm{~mm}$.

Head: Width about 1.12 times the length. Light yellow-brown in color except area around mouth and collar which are slightly darker. Mental plate with a strong median trilobed tooth and with 6 (5-7) well developed teeth on each side. Seta 1-C single, small, seta 4-C 7-12 branched, seta 5-C 5-8 branched, 6-C 2-3 branched, longer than seta 4-C. Seta 7-C 4-9 branched, seta 9-C large, 2-4 branched. Seta 11-C 8-17 branched. Setae 7, 9, 11, 16-C well developed with aciculated branches. Antenna length about 0.20 times the head; shaft about the same breadth from base to apex. Integument smooth; yellow in color. Seta 1-A inserted at basal 0.42 length of antenna.

Thorax: With long and prominent aciculated pleural setae. Setae 9-12-M, T arising from a common tubercle.

Abdomen: Setae 2-I-VII yellow to light brown. Comb scales 3-6 in one irregular row, lightly pigmented and with rounded blunt apices; fringe present. Siphon short and stumpy. Siphonal index 1.4, pigmented brown. Seta 1 usually single $(1,2)$, inconspicuous, inserted at basal about 0.22 length of siphon. Gills long, with bluntly rounded apices; ventral pair slightly longer than dorsal pair.

Remarks. Armigeres moultoni was described originally from Kuching, Sarawak (Edwards, 1914). We examined the type specimens (syntype: Sarawak, Kuching, 23 II, 1914287, ऽ , J. C.; Moulton) of Ar. moultoni in the Natural History Museum, London. The genitalia of the type is illustrated (Fig. 7A). The adults of Ar. moultoni are morphologically very similar to Ar. alkatirii Toma, Miyagi and Syafruddin, 1995 from Sulawesi, Indonesia in coloration of adult sternites and immature stages (Toma et al., 1995). However, the 2 species differ markedly in the following characters: Abdominal sternum II in Ar. moultoni is entirely white, and the gonocoxite is triangular in shape with several long setae apically and gonostylus inserted subapically before the tip of gonocoxite in the male genitalia. Whereas in Ar. alkatirii, sternum II is entirely black and the apical part of gonocoxite is slender with one very long hornlike inner curved seta apically and 


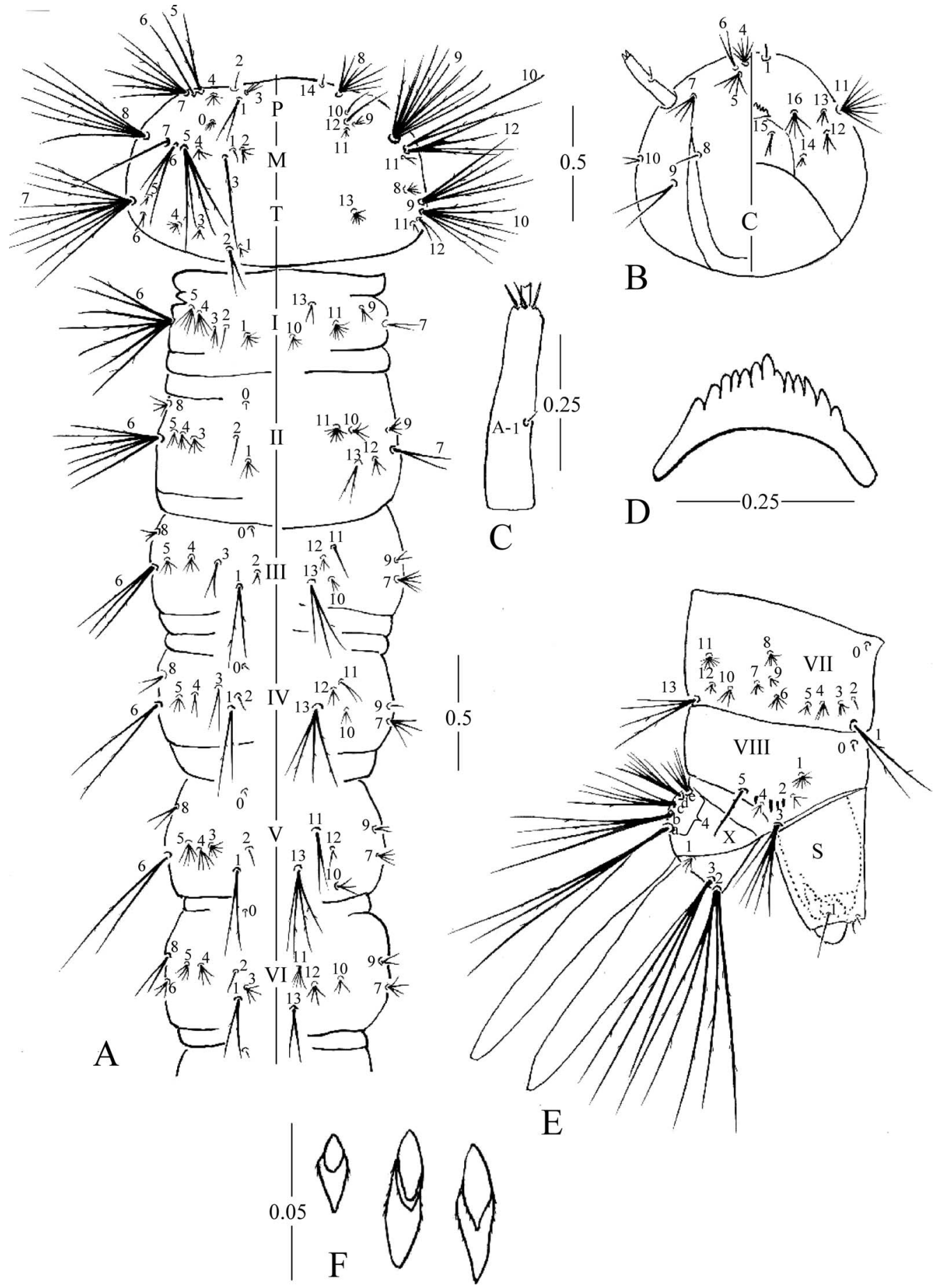

Fig. 9. Fourth-instar larva of Armigeres (Armigeres) moultoni. A, thorax and abdominal segments I-VI (dorsal and ventral aspects); B, head (dorsal and ventral aspects) of exuviae; C, antenna; D, dorsomentum (ventral aspect); E, abdominal segments VII, VIII, X and siphon (S) (lateral aspect); F, comb scales. Scales: mm. 
Table 6. Chaetotaxy of the fourth-instar larvae of Armigeres (Armigeres) moultoni

\begin{tabular}{|c|c|c|c|c|c|c|c|c|c|c|c|c|}
\hline \multirow{2}{*}{$\begin{array}{c}\text { Seta } \\
\text { no. }\end{array}$} & \multirow{2}{*}{ Head } & \multirow{2}{*}{\multicolumn{2}{|c|}{$\frac{\text { Thorax }}{\mathrm{M}}$}} & \multirow[b]{2}{*}{$\mathrm{T}$} & \multicolumn{8}{|c|}{ Abdominal segments } \\
\hline & & & & & I & II & III & IV & $\mathrm{V}$ & VI & VII & VIII \\
\hline 0 & - & $6-11$ & - & - & - & 1 & 1 & 1 & 1 & 1 & 1 & 1 \\
\hline 1 & 1 & $1-3^{*}$ & $1(1-3)$ & $2-6$ & $6-10$ & $2-6$ & $2(1-3)^{*}$ & $1-4^{*}$ & $1,2^{*}$ & $2,3^{*}$ & $2(2-8)^{*}$ & $8-13$ \\
\hline 2 & - & $1-4$ & $1-5$ & $1-3^{*}$ & $1(1-4)$ & $1(1,2)$ & 1,2 & 1,2 & $1(1-3)$ & $1(1,2)$ & $1(1,2)$ & $3-5$ \\
\hline 3 & - & $2-6$ & $1^{*}$ & 3,4 & $3-12$ & $4-10$ & $2-4$ & $1-3$ & $6-10$ & $4-10$ & $4-8$ & $4-11^{*}$ \\
\hline 4 & $7-12$ & $4-9$ & $4-9$ & $5-10$ & $5-11$ & $5-10$ & $4-10$ & $2-5$ & $4-8$ & $5-7$ & $3-6$ & $3-7$ \\
\hline 5 & $5-8$ & $2-4^{*}$ & $4-12^{*}$ & $1-3$ & $4-6$ & $3-6$ & $3-9$ & $4-7$ & $5-9$ & $4-7$ & $3-7$ & $1(1,2)^{*}$ \\
\hline 6 & $2(2,3)$ & $1,2^{*}$ & $3-7^{*}$ & 2,3 & $5-10^{*}$ & $4-9 *$ & $2,3^{*}$ & $2-4^{*}$ & $2(1-3)^{*}$ & $3-9$ & $4-10$ & $1-X=4-11$ \\
\hline 7 & $4-9 *$ & $6-12^{*}$ & $1-3^{*}$ & $4-11^{*}$ & $2-5$ & $2-4^{*}$ & $5-7$ & $4-8$ & $4-8$ & $4-8$ & $3-5$ & \\
\hline 8 & $2-5$ & $7-11^{*}$ & $6-13^{*}$ & $5-12$ & - & $4-7$ & $3-7$ & 2,3 & 2,3 & $1-4$ & $6-12$ & $2-X=5-8^{*}$ \\
\hline 9 & $2-4^{*}$ & $2-8$ & $11-17^{*}$ & $5-9 *$ & $2-4$ & $3-5$ & $1-4$ & $1-3$ & $2-4$ & 2,3 & $3-7$ & \\
\hline 10 & $2-4$ & 1 & $2-4^{*}$ & $7-12^{*}$ & $4-8$ & $4-7$ & $3-6$ & $2-5$ & $2-4$ & $3-5$ & $2-5$ & $3-X=3,4^{*}$ \\
\hline 11 & $8-17^{*}$ & $2-5$ & $2-4$ & $1-4$ & $8-11$ & $8-17$ & 1,2 & 2 & $2(1,2)$ & $5-13$ & $8-12$ & \\
\hline 12 & $2-6$ & $1(1,2)^{*}$ & $4-8^{*}$ & $2-6$ & - & $3-7$ & $3-5$ & $3-5$ & $2-5$ & 3,4 & $2-5$ & $4-\mathrm{Xa}=2-4^{*}$ \\
\hline 13 & 2,3 & - & - & $7-10$ & 2,3 & $2-4^{*}$ & $3-8^{*}$ & $2-6 *$ & $2-6^{*}$ & $1-4$ & $3(1-4)^{*}$ & $\mathrm{Xb}=3-7^{*}$ \\
\hline 14 & $3-6$ & $1(1,2)$ & - & - & - & - & - & - & - & - & - & $\mathrm{Xc}=4-9^{*}$ \\
\hline 15 & 2,3 & - & - & - & - & - & - & - & - & - & - & $\mathrm{Xd}=6-10^{*}$ \\
\hline 16 & $5-8^{*}$ & - & - & - & - & - & - & - & - & - & - & $\mathrm{Xe}=5-10^{*}$ \\
\hline
\end{tabular}

* Aciculated; obsolete and missing setae are shown with a hyphen (-).

Specimens examined: 8 fourth-stage larvae.

gonostylus inserted distinctly before the tip of gonocoxite. Sternum VII is black. In the original description of Ar. alkatirii (Toma et al., 1995), the coloration of sternum VII is mostly black but the sternum VII in the illustration (Fig. 1B in the original description) is white and apparently mistaken as black color.

Biological Notes. Immatures of Ar. moultoni were not as common as Ar. jugraensis.

Distribution. Malaysia: East (Sarawak) and Peninsular (Selangor). Also reported from Indonesia (Sumatra, Java, Sulawesi).

\section{Armigeres (Armigeres) malayi (Theobald), 1901}

(Fig. 10)

Uranotaenia malayi Theobald, 1901. Mongraph of the Culicidae or mosquitoes 1: 258. Type locality: Klang Jungle, Selangor, Malaysia.

Armigeres (Armigeres) malayi (Theobald): Edwards, 1917, Bull. Entomol. Res. 7: 207 (万*); Thurman, 1959, Univ. Maryland Agr. Exp. Sta. Bull. A-100: 88 (우, ơ*, P*); Steffan, 1968, J. Med. Entomol., 5: 141 (우, ơ*, $\mathrm{P}^{*}, \mathrm{~L}^{*}$ ).

Specimens Examined. The following specimens were collected as larval and pupal stages from fallen coconut fruits at Sampadi and Samarahan, Kuching, Sarawak in September 2005 and Asajaya, Kuching, Sarawak in August 2006. 20주, 2웅(060829-19) on pin with

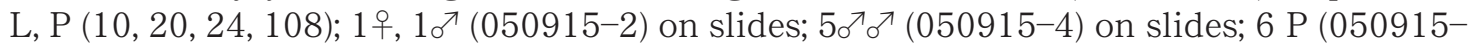
4) on slides; 1 whole larva (060829-1) on slide.

Remarks. Armigeres malayi (Fig. 10H) was well described for all stages except egg based on the type specimens from Malaysia (Edwards, 1917), and the specimens from Thailand (Thurman, 1959), Philippines (Delfinad, 1966) and Papua New Guinea (Steffan, 1968). 


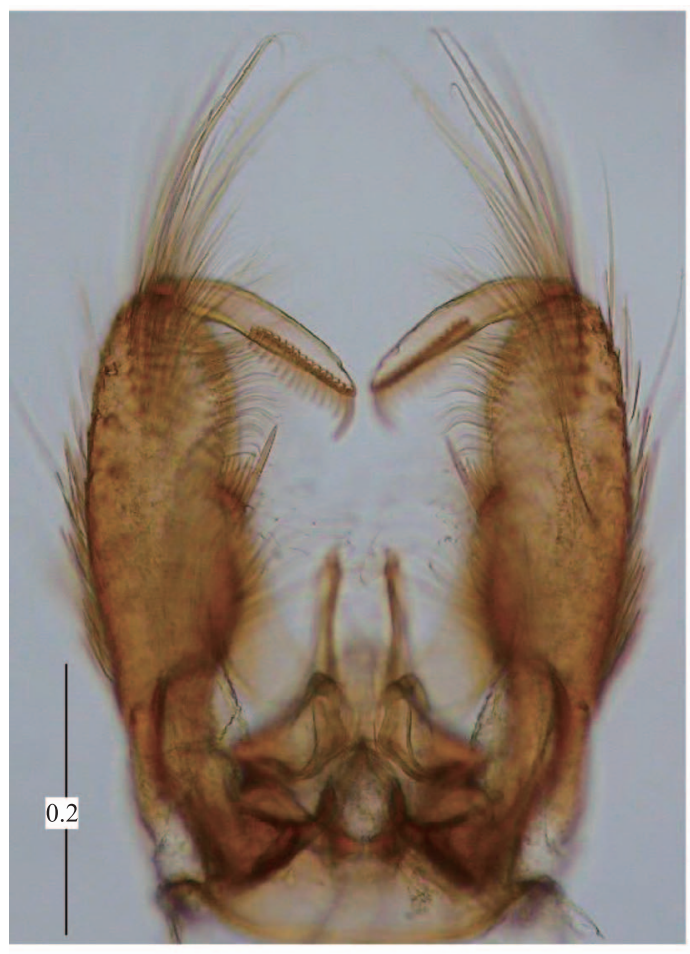

A
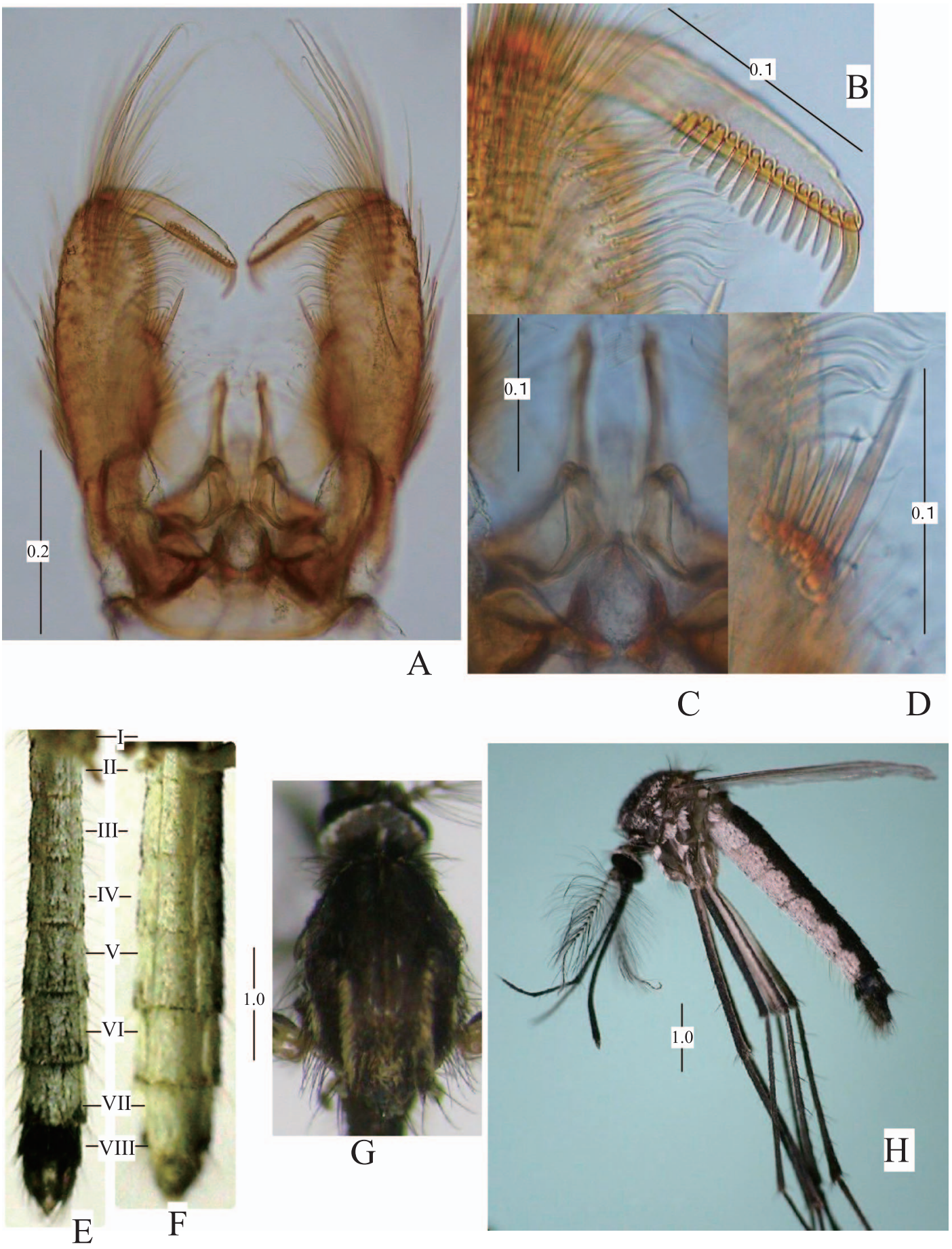

Fig. 10. Adult male (A-E, G, H) and female (F) of Armigeres (Armigeres) malayi. A, structures of genitalia (ventral aspect); B, gonostylus; C, phallosome (ventral aspect); D, dorsomesal lobe (BDL) with lanceolate setae; E and F, abdominal sterna (ventral aspect); G, scutum (dorsal aspect); H, adult (lateral aspect). Scales: mm. 
Armigeres malayi is morphologically similar to Ar. jugraensis in dark scales on sternum VIII in the male but differing by white scaled sternum VII in the male (Fig. 10E) and on all sterna in the female (Fig. 10F), and also white scales on the clypeus in both sexes. Border of scales around scutum is black, and with conspicuous white scales in males but not in females. Scutum is dark with white scaling along edges of scutum and has a pair of distinct yellowish brown lateral prescutellar and supraalar scale lines, and median prescutellar lobe with yellowish brown scales (Fig. 10G). The characteristics of male genitalia (Fig. 10A-D) are constant as characters to distinguish from Ar. jugraensis, and show a basal dorsomesal lobe with a row of 4-6 stout spiniforms, and mesal spiniform almost 2 times as long (Fig. 10D). Female legs: Foreunuges are large, subequal in size, both with a submedian tapering tooth. Male legs: Foreungues are large, unequal in size, larger one is about 2 times the length of the smaller, with a submedian tooth, smaller one is simple. The pupa of Ar. malayi is characterized by paddle seta 1 frequently with 2 or 3 branches. Seta 6-VI has more than 2 branches.

Biological Notes. Armigeres malayi is very common in Sarawak. The larvae occur in various types of containers holding heavily polluted water, with Ar. confusus, Ar. moultoni and Ar. setifer in fallen coconut fruits. The females may bite human but could not be collected by human baited method carried out in the Matang National Park, Kuching.

Distribution. Malaysia: East (Sarawak) and Peninsular (widely distributed). Also reported widely from India, Thailand, South China, Indonesia, Papua New Guinea and the Philippines.

\section{Armigeres (Armigeres) setifer Delfinado, 1966}

(Fig. 11)

Armigeres (Armigeres) setifer Delfinado, 1966. Mem. Am. Entomol. Inst. 7: 87 (万(*).

Type locality: Palawan, Philippines; Toma et al., 2007, Med. Entomol. Zool. 58: 283 (ㅇ*ᅮ, 。 $\left.*, \mathrm{P}^{*}, \mathrm{~L}^{*}\right)$.

Specimens Examined. Holotype of male on slide (Holotype of male on slide, Palawan, Mantalingajan, Pinigisan, 7, IX. 1961) in Smithsonian Institution, Washington, DC.

Remarks. Armigeres setifer was originally described based on a male collected from Palawan, Philippines (Delfinado, 1966); larval and pupal stages were described in detail and illustrated based on specimens collected from Sampadi, Kuching, Sarawak (Toma et al., 2007). We (Toma and Miyagi) examined the type specimens of Ar. setifer (Fig. 11A). Female legs: Foreungues are large, subequal in size, both with a tapering submedian tooth. Male legs: Foreungues are large, unequal in size, the larger one with a submedian blunt-tipped tooth. On the bases of coloration of sterna and terga in adults, Ar. setifer (Fig. $11 \mathrm{C}-\mathrm{G}$ ) resembles Ar. moultoni because the sternum II is entirely white in both, sterna III-VI are white basally with more or less black scales apically, but the male genitalia is different between the two species (Figs. 7A and 11A). The larvae of Ar. setifer are characterized by head seta $9-\mathrm{C}$ (long with 5-10 branches) and 11-C (long with 7-18 branches). The pupae are easily distinguished from any other species in Sarawak by very strong paddle seta 1 with 4-9 branches and a short trumpet with an index less than 1 (Toma et al., 2007).

Biological Notes. Immatures of Ar. setifer were commonly found in fallen coconut fruits. 

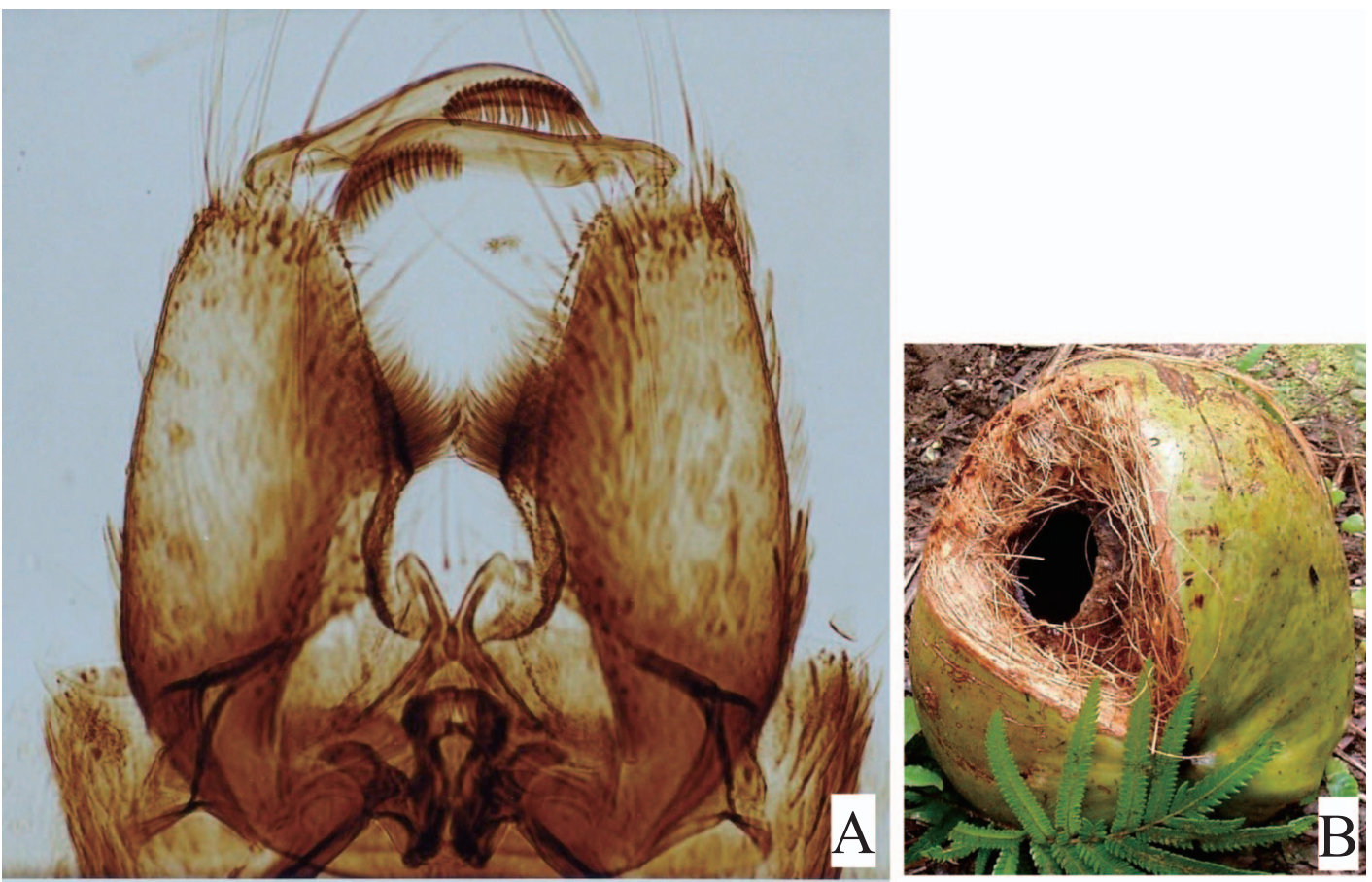

0.2

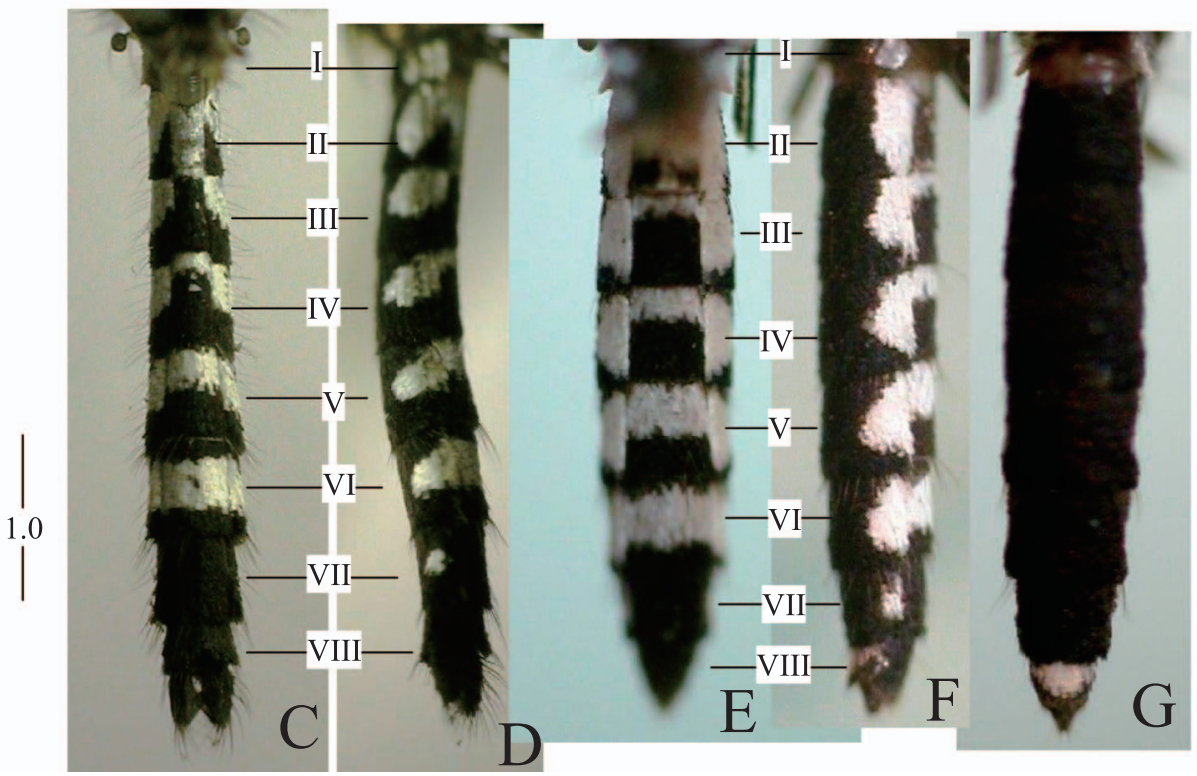

Fig. 11. Adult male (A, C, D) and female $(\mathrm{E}-\mathrm{G})$ of Armigeres (Armigeres) setifer. A, structures of genitalia (holotype, ventral aspect); $\mathrm{B}$, fallen coconut fruit with small hole; $\mathrm{C}$ and $\mathrm{E}$, abdominal sterna (ventral aspect); D and F, abdomen (lateral aspect); G, abdominal terga (dorsal aspect). Scales: $\mathrm{mm}$. 
The females bite humans during the daytime inside a shed.

Distribution. Malaysia: East (Sarawak). Also reported from the Philippines (Palawan Is.).

Key to 5 species of the subgenus Armigeres occurring in fallen coconut fruits with openings from coconut farms in coastal areas of Kuching, Sarawak

Adults

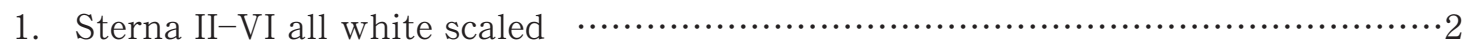

- Sterna II-V each with apical dark band, sternum VI variable, sternum VII dark $\cdots 4$

2. Clypeus white scaled; scutum lacking pale border in both sexes. $\cdots \cdots \cdots \cdots \cdot$..... malayi

- Clypeus bare; scutum with anterior and lateral pale border (indistinct in females of

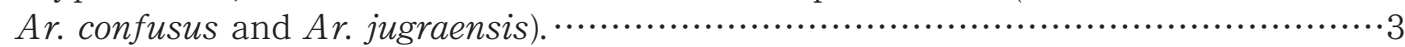

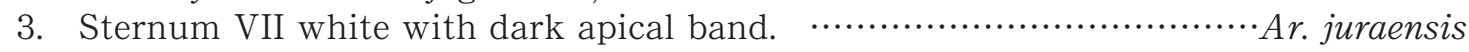

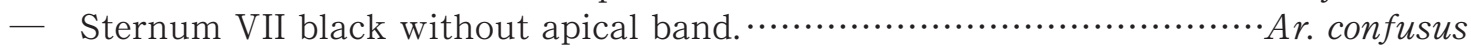

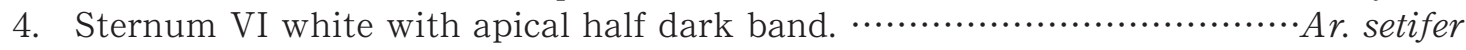

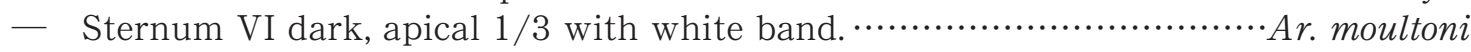

Male genitalia

1. Gonocoxite pointed with many long curved setae apically; gonostylus inserted distinctly before the tip of gonocoxite, broad in middle with a row of 4 or 5 teeth

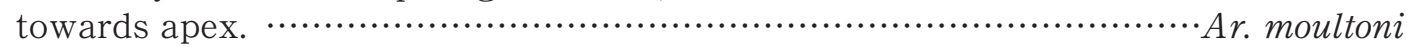

- Gonocoxite not pointed apically; gonostylus inserted at apex of gonococxite, outer margin slightly convex, more than 10 teeth closely spaced, arranged in a row. $\cdots \cdots 2$

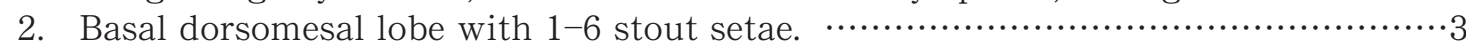

- Basal dorsomesal lobe without stout setae but with a tuft of dense setae. $\cdots \cdots \cdots \cdots \cdot \cdots 4$

3. Basal dorsomesal lobe with 1 stout seta; gonostylus with more than 20 teeth......... ........................................................................... jugraensis

- Basal dorsomesal lobe with 4-6 stout setae, the inner one longer. $\cdots \cdots \cdots \cdot \cdots \cdot$.... Ar. malayi

4. Gonostylus with 17-20 teeth arranged in a row on apical $0.36-0.44$; basal dorsomesal

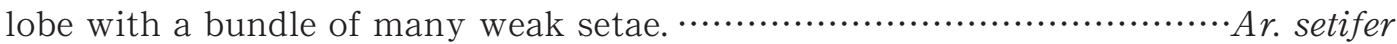

- Gonostylus with 20-22 teeth arranged in a row on apical 0.6; basal dorsomesal lobe with a bundle of about 10 well developed setae. ..Ar. confusus

Pupae

1. Paddle seta 1 (P-1) very long, with more than 4 branches; trumpet short (index $<1.0$ ).

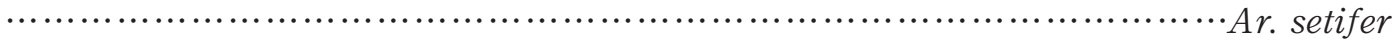

- P-1 absent, or short, with 1-3 branches, trumpet longer than width (index $>1.5$ ). $\cdots 2$

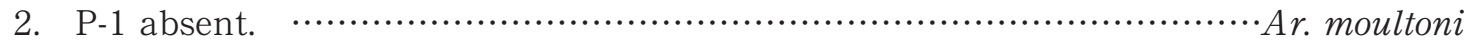

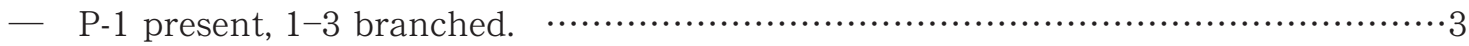

3. P-1 usually bifid, rarely 3 branched; midrib moderately pigmented halfway to apex.

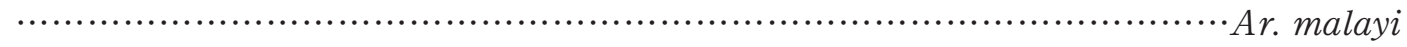

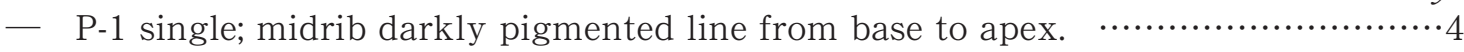

4. Abdominal seta 3-III weak, 1-6 branched; trumpet apparently longer than width

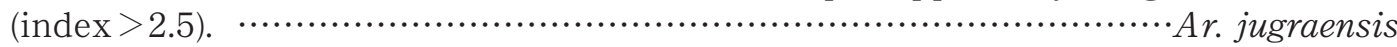

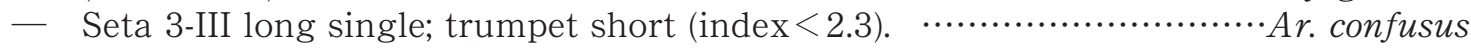

Fourth-instar larvae

1. Head seta 9-C longer than 1.5 times of antenna length, with more than 5 (5-10) branches; 11-C long, black usually with more than 7 (7-18) branches; 5-VIII weak 
5-9 branches.

Ar. setifer

- Seta 9-C shorter than 1.5 times of antenna length, with usually 2-4 branches; 11-C

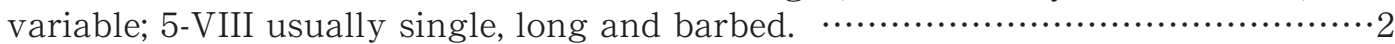

2. Seta 11-C long, black usually with more than 8 branches; comb scales $3-6$ in a row,

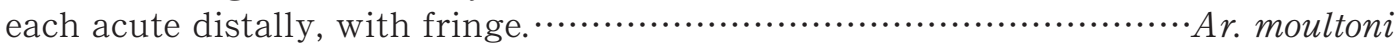

- Seta 11-C weak, pale, with less than 8 branches; comb scales variable.................. 3

3. Abdominal setae 6-I, II 1-2 branched; comb scales 5-8 in single row, each acute

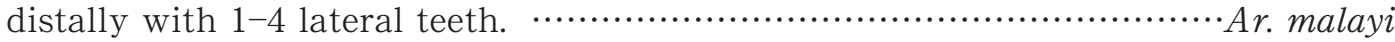

- Setae 6-I, II more than 4 branched: comb scales more than 6 in an irregular row, each

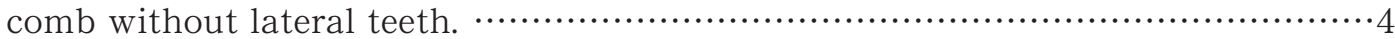

4. Abdominal setae 13-IV, V 2 branched: comb 11-20 teeth, each gently acute distally

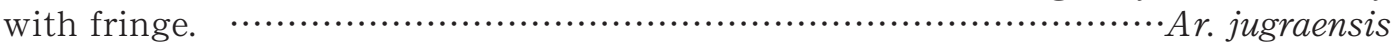

- Setae 13-IV, V 3-5 branched; comb scale 6-11 teeth, each rounded distally with fringe. Ar. confusus

\section{ACKNOWLEDGEMENTS}

We wish to thank Dr. Yong Hoi-Sen, Professor Emeritus (Genetics and Zoology), University of Malaya for his valuable advice and cooperation in the field study. We also thank Dr. Ralph E. Harbach, the Natural History Museum, Cromwell Road, London, U. K. and Dr. Leopoldo M. Rueda, Walter Reed Biosystematic Unit, Department of Entomology, Walter Reed Army Institute of Research, for their kind support during our study of the type specimens. Finally, we wish to thank Mr. Keisyo Miyagi, Director of Ocean Health Corporation for his kind support in various ways.

This study was carried out with the cooperation of the Sarawak Museum, Kuching, Sarawak and permission to conduct research on biological resources/collect samples of biological resources for research purpose and permits No. 8/2005, NPW/907/4/2-96 from the Director of Forests, Sarawak.

\section{REFERENCES}

Barraud, P. J. 1934. Family Culicidae. Tribes Megarhinini and Culicini. The fauna of British India, including Ceylon and Burma. Diptera. Vol. 5. 463 pp., illus., 8 pls., 1 map. Taylor and Francis, London.

Belkin, J. N. 1962. The mosquitoes of the South Pacific (Diptera: Culicidae). Vols. I and II. 608 and 412 pp., University of California Press, Barkeley and Los Angeles.

Bonne-Wepster, J. and Brug, S. L. 1937. Nederlandsch-Indische culicinen. Geneesk. Tijdschr. Ned. -Ind., 77: 515617.

Brug, S. L. 1931. Culiciden der Deutschen Limnologichen Sunda-Expedition. Arch. Hydrobiol., Suppl.: 1-42, illus. Delfinado, M. D. 1966. The culicine mosquitoes of the Philippines, tribe Culicini (Diptera, Culicidae). Mem. Am.

Entomol. Inst., 7: 1-252, illus.

Edwards, F. W. 1914. New Culicidae from Borneo and Hong Kong. Bull. Entomol. Res., 5: 125-128.

Edwards, F. W. 1915. Diagnoses of new Bornean Culicidae. Bull. Entomol. Res., 5: 283-285.

Edwards, F. W. 1917. Notes on Culicidae, with descriptions of new species. Bull. Entomol. Res., 7: 201-229, illus.

Harbach, R. E. and Knight, K. L. 1980. Taxonomists' Glossary of Mosquito Anatomy. 415 pp., Plexus Publishing Inc., New Jersey.

Harbach, R. E. and Knight, K. L. 1981. Corrections and additions to taxonomists' glossary of mosquito anatomy. Mosq. Syst., 13: 201-217.

Knight, K. L. and Stone. A. 1977. A catalog of the Mosquitoes of the World (Diptera: Culicidae). 2nd edition. Vol.

6. 611 pp., Thomas Say Foundation, Entomol. Soc. Am., Maryland.

Leicester, G. F. 1908. The Culicidae of Malaysia. Stud. Inst. Med. Res. F. M. S., 3: 18-261. 
Macdonald, W. W. 1957. Malaysian Parasites. Part XVI. An interim review of the non-anopheline mosquitoes of Malaya. Stud. Inst. Med. Res. Federated Malay States, 28: 1-34.

Steffan, W. A. 1968. Armigeres of the Papuan subregion (Diptera: Culicidae). J. Med. Entomol., 5: 135-159, illus. Thurman, E. B. 1959. A Contribution to a Revision of the Culicidae of Northern Thailand. Bull. A-100, 182 pp., illus., University of Maryland Agriculture Experiment Station, Maryland.

Toma, T. Miyagi, I. and Syafruddin, 1995. Description of Armigeres (Armigeres) alkatirii, a new species from Sulawesi, Indonesia (Diptera: Culicidae). Mosq. Syst., 27: 110-117.

Toma, T., Miyagi, I., Okazawa, T. and Leh C. 2007. Redescription of Armigeres (Armigeres) setifer Delfinado, 1966 (Diptera: Culicidae) collected from Kuching, Sarawak, Malaysia. Med. Entomol. Zool., 58: 283-290.

WBRU, 2010. Water Reed Biosystematic Unit, Smithsonian Institution [accessed January, 2010]. Available from: http://mosquitocatalog.org/default.aspx?pgID = 2 